\title{
Viscosity and Constitution of Slags Associated With Metallorthermic Extraction of Some Less Common Metals
}

\author{
R.C. Behera, U.K. Mohanty, and A.K. Mohanty \\ Department of Metallurgical Engineering, \\ Regional Engineering. College, \\ Rourkela, 769008 India
}

\section{CONTENTS}

\section{ABSTRACT \\ INTRODUCTION}

1. STRUCTURE AND VISCOSITY OF SILICATE MELTS

1.1. Flow in Molten Silica

1.2. Flow in Binary Melts

1.3. Interrelation Conductance and Viscosity

1.4. Polycomponent Melts

1.5. Role of Ionic Interaction on Viscosity

1.6. Complex Melts

1.7. Calcium Fluoride Addition to Silicate Melts

1.8. Role of Other Constituents 1.8.1. Slags with Iron Oxides 1.8.2. Slags with Barium Oxide 1.8.3. Minor Constituents

1.9. Effect of Temperature on Viscosity
2. VISCOSITY MEASUREMENT OF SOME INDUSTRIAL SLAGS 68

2.1. Blast Furnace Slags 68

2.2. Blast Furnace Slags with Titanium Oxides $\quad 68$

2.3. High Titania Slags 69

3. THERMOPHYSICAL PROPERTIES OF ALUMINO-THERMIC SLAGS 69

3.1. Liquidus Temperature of Alumina Based Melts

3.2. Role of $\mathrm{CaF}_{2}$ in Aluminothermic Slags

3.3. Viscosity of Aluminothermic Slags

3.3.1. Ferrotitanium Slag 71

3.3.2. Low Carbon Fer rochrome Slag 72 3.3.3. Ferrosilicozirconium Slag 72 3.3.4. Ferroniobium Slag $\quad 72$ CONCLUSIONS $\quad 73$ REFERENCES 


\section{ABSTRACT}

Slags resulting from aluminothermic reduction of oxides for production of less common metals and their ferroalloys contain a high percentage of alumina and have a high melting point as well as being highly viscous. Alumina exhibits both covalent and ionic bonding under different conditions. It is expected that high alumina slags may behave like silicate melts that contain silica having a covalent bond. Consequently, an exhaustive review on structural aspects of silicate melts, their viscosity, activation energy of viscous flow, conductance, etc., has first been made. The role of fluorides and other constituents on the viscosity of silicate melts has also been discussed. Some investigation results on viscosity measurement of some industrial blast furnace slags with and without titanium oxides and high titania slags have been presented to appreciate the structure of silicate melts. Review of relevant literature on the liquidus temperature and role of calcium fluoride on the thermo-physical properties of alumina-based melts has been made. Finally, the meagre information available on slag viscosity of some aluminothermic slags such as those of $\mathrm{FeTi}, \mathrm{FeCr}, \mathrm{FeSiZr}$, and $\mathrm{FeNb}$ has been furnished.

\section{INTRODUCTION}

The viscosity of metallurgical slags has an important influence on furnace operation. Viscosity helps to govern the reaction rates by its effect on diffusion of ions through the liquid slag to and from the metal/ slag interface. Where the metal droplets have to trickle through the slag, a high viscosity slag would increase their residence time in the slag bath. The useful effect of this action is that it provides a longer time for chemical exchanges to occur between the two media, but where slag-metal separation is the sole aim, a slag of high viscosity has to be avoided. Especially in metallothermic processes, viscosity has a substantial effect on the speed and completeness of reduction reactions and also on the rate at which the metal droplets sink through the liquid slag layer. The transfer of heat between the slag and metal is also affected by the viscosity of the slag. For example, in a liquid of low viscosity, heat transfer by convection is rapid. Further, a low viscosity slag facilitates the escape of gases from the solidified metal in the case of electroslag refining processes.
On the other hand, the refractory is not damaged very much by a high viscosity slag.

Apart from the above, knowledge of variation of viscosity with composition and temperature helps in predicting the structure of liquid slags.

Many investigations have been carried out over the past 50 years on the viscosity of silicate slags with varying composition, and the structure of the melts have been predicted from these studies. Similarly, viscosity studies of blast furnace slag, steelmaking slag, high titania slag, etc. have provided useful information on the compositional adjustments of the respective slags needed to obtain the best metallurgical results. Relatively little has been done on the viscosity of high alumina slags resulting from aluminothermic reduction of metal oxides. The authors, before commencing with a detailed study of the viscosity and liquidus temperature of aluminothermic slags, thoroughly reviewed the literature on viscosity of slags in general and the liquidus temperature of the relevant melts. Some of the related literature is summarized here.

\section{STRUCTURE AND VISCOSITY OF SILICATE MELTS}

Adequate literature is available on viscosity studies of binary, ternary, and quartenary oxide systems with silica and lime as the main components and alumina and magnesia as additional constituents. Determination of viscosity $(\mu)$ and activation energy of viscous flow $\left(\mathrm{E}_{\mu}\right)$ through these investigations has helped in predicting the structure of the slags. Hence we first present a brief discussion on the nature of viscous flow.

Experimental determinations of electrical conductivity $/ 1 /$, electron transport $/ 2 /$, viscosity $/ 3 /$, and expansivity /4/ have established that molten oxide slags are ionic in nature like halide melts but have very high viscosity and high activation energy of viscous flow in comparison to halides. (The $\mu$ and $\mathrm{E}_{\mu}$ of halides range from $0.5-5 \mathrm{cps}$ and $6-10 \mathrm{kcal} /-$ mole at temperatures much above the liquidus $/ 5 /$.) The type, size, and structure of the various ions present in the slag melt have a direct effect on slag viscosity because viscosity is determined by the more slowly moving anions (i.e., large ions). On the other hand, the structure and size of these ions depend on the type of constituents present in the slag. In general, covalent oxides when molten are very viscous, unlike molten ionic oxides, and hence the relative 
proportion of these two types of oxides will decide the value of viscosity.

\subsection{Flow in Molten Silica}

In the case of pure molten silica the building units are $\mathrm{SiO}_{4}$ tetrahedra where each silicon ion is tetrahedrally coordinated with four oxygen ions while each oxygen ion is linked to two $\mathrm{Si}^{4+}$ ions leading to a three-dimensional network. Much of the three-dimensional bonding present in the solid silica is retained, although there may be a change from long- to shortrange ordering during melting. This gives low conductance, high viscosity, and high value for activation energy of viscous flow. The high value of $E_{\mu}$ of molten silica $(135 \mathrm{kcal} /$ mole $/ 6 /)$ suggests that the movement of flow units involves the breaking of Si$\mathrm{O}$ bonds.

\subsection{Flow in Binary Melts}

When a basic metal oxide is added, each added oxygen ion enters the network and separates the corners of the two tetrahedra while the added cation remains adjacent to the negative charges, as shown in eqs. 1(a) and 1(b).

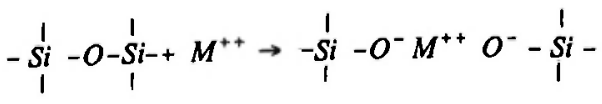

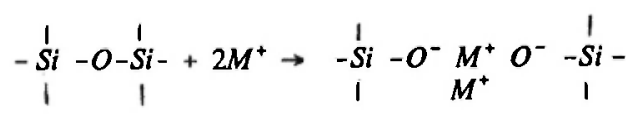

Thus the oxygen bridges between the groups are broken, the driving force for this breakdown process being the attraction between the cation and the unshared oxygen (or singly bonded oxygen). The degree of breakdown depends on the type and amount of metal oxide added. It is observed that while bivalent metal cations tend to link the network by bridging two oxygens, monovalent ones do not $/ 3 /$. It is generally agreed that breaking down the structure results in smaller and smaller silicate groups and that viscosity is lowered. It is believed that the cations are randomly distributed throughout the lattice, their presence giving rise to two general effects /3/: (1) weak points are introduced into the silica network by the rupture of Si-O bonds; and (2) the Si-O bonds near the metal ion are weakened due to the polarizing effect of the cation, so that a general loosening effect in the lattice occurs. This is illustrated in the simplified two-dimensional representation in Fig. 1.

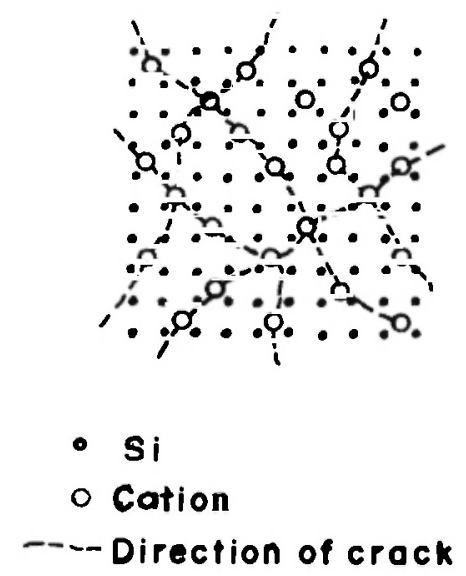

Fig. 1: Mechanism of collapse of silicate lattice.

The viscosity of silicates decreases with rising temperature and is represented by

$$
\mu=\mathrm{Ae}^{\mathrm{E}_{\mu} / \mathrm{RT}}
$$

Hence the plots of $\log \mu$ vs $1 / \mathrm{T}$ are reasonably linear with some minor exceptions. For example, in silicates with more than $41 \% \mathrm{CaO}$, the slope decreases with rising temperature and is less above $1700^{\circ} \mathrm{C}$ than below it. It may be mentioned here that a linear relationship of $\log \mu$ vs $1 / \mathrm{T}$ means $\mathrm{E}_{\mu}$ is constant, i.e., degree of polymerization is constant over the range of temperature. If the degree of polymerization changes, there will be a continuous change of liquid structure with temperature and the plot will give a curved line. When a sudden change of liquid structure occurs, a break in the straight line relationship is obtained.

Viscosity measurement of binary silicate melts $/ 3,6 /$ have yielded the values of $E_{\mu}$, and a plot of this $E_{\mu}$ against percentage of metal oxide shows that $E_{\mu}$ falls rapidly from $135 \mathrm{kcal} / \mathrm{mole}$ for pure silica to 20 $40 \mathrm{kcal} / \mathrm{mole}$ as the network is broken down. The activation energy of viscous flow is related to the energy required to move one silicate group, or a major part thereof, with respect to the other. When the silicate groups become smaller, the number of associated negative charges become less. Thus the number of ionic bonds which have to be broken or distorted to enable the group to move becomes less and, therefore, one expects the value of $E_{\mu}$ to decrease. In the case of silicates, it is seen that some 
10-12 mole percent of alkali metal oxide and 15-20 mole percent of alkaline earth oxide are sufficient to bring down the value of $E_{\mu}$ from 135 to $40 \mathrm{kcal} /$ mole, and, thereafter, the rate of decrease becomes much smaller.

The effects of monovalent and divalent metal oxides are different because at equimolar compositions there will be twice as many monovalent cations as divalent ones, and the divalent cations tend to maintain the continuous bonding of the lattice by bridging oxygen atoms, as mentioned earlier. Hence, by addition of group II metal oxides, the decrease of $\mathrm{E}_{\mu}$ will be more gradual, i.e., the collapse of the silica framework will only occur when comparatively more metal oxides have been added. In the case of Group II metal oxide systems, $\mathrm{E}_{\mu}$ is independent of the cationic species at all compositions up to 55 mole percent of metal oxide, whereas for Group I systems, this is only true up to about 35 mole percent. This smaller composition range is attributed to steric effects due to the larger number of monovalent cations present at higher concentrations of metal oxide. Moreover, $\mathrm{E}_{\mu}$ for alkali silicates is lower than those of alkaline earth silicates.

From an expansivity study of alkali metal silicates, Bockris et al. /4/ calculated the number of broken bridges and inferred that an addition of up to 12 mole percent of alkali metal oxide results in a random breakdown of this silicate network so that threedimensional bonding still exists almost throughout the melt. It is proposed that, within this composition, the cations are held in cages as shown in Fig. 2. The abrupt change of expansivity (an increase by approximately a factor of 83 ) and activation energy of viscous flow at 12 mole percent alkali metal oxide addition indicates that there is a change in silicate structure in this region. At higher concentrations the network breaks down more or less completely to give discrete globular anions of the type shown in Fig. 3.

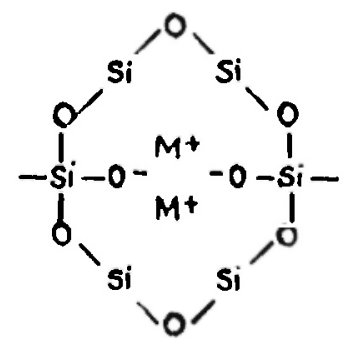

Fig. 2: The two dimensional silicate cages (a)

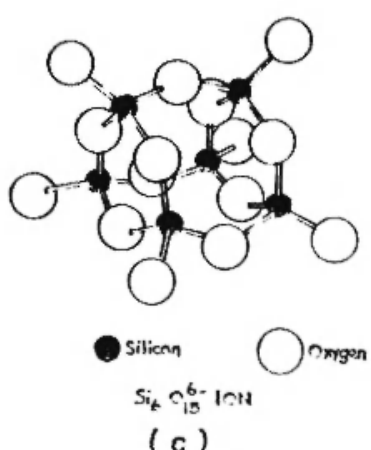

(c)

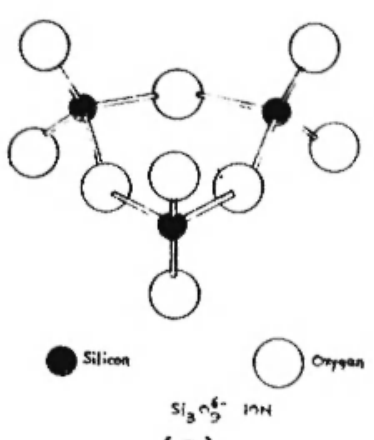

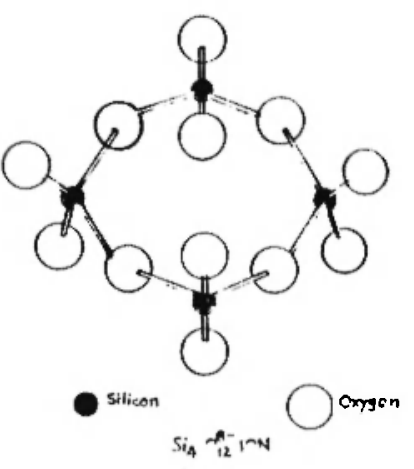

(b)

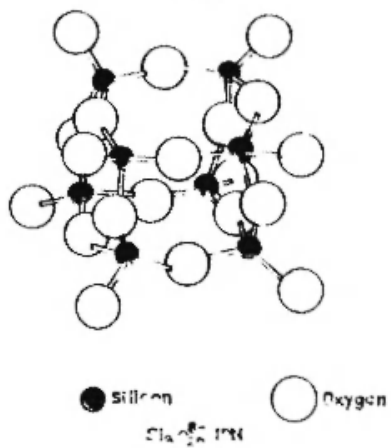

(d)

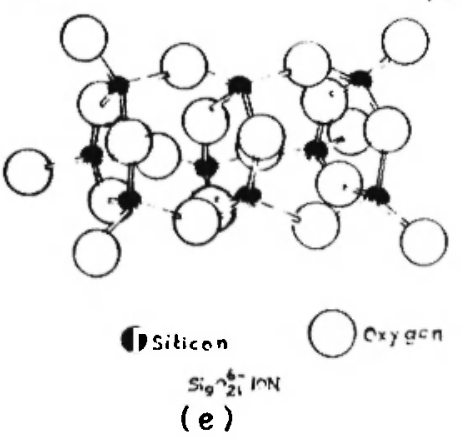

Fig. 3: Globular anions existing in silicate melts

From the measurement of various physical properties of silicate melts, different structural models have been proposed to explain the change of properties with change of composition. The chain formation concept and the discrete anion model proposed by Bockris and coworkers $/ 3,4,6 /$ is the most successful structural model for the silicate melts. According to this model, at the orthosilicate composition (66 mole percent of $\mathrm{CaO}$ ), the melt is considered to consist of $\mathrm{SiO}_{4}^{4-}$ tetrahedra. Addition of silica to this composition results in polymerization of these tetrahedra to give chains, the lengths of which increase with rising silica content. The empirical formulae of the anions in the range of $\mathrm{Si} / \mathrm{O}$ ratio of $0.25: 0.333$ are presented in Table 1 . The chain formation concept holds satisfactory from 66 mole percent of molar oxide (MO) to 50 mole percent. 
TABLE 1

EMPIRICAL FORMULAE OF ANIONS /6/

\begin{tabular}{lcc}
\hline Si/O & Percent molar oxide & Empirical formulae \\
\hline 0.250 & 66 & $\mathrm{SiO}_{4}^{4-}$ \\
0.286 & 60 & $\mathrm{Si}_{2} \mathrm{O}_{7}^{6-}$ \\
0.300 & 57 & $\mathrm{Si}_{3} \mathrm{O}_{10}^{3-}$ \\
0.307 & 55 & $\mathrm{Si}_{4} \mathrm{O}_{13}^{10-}$ \\
0.312 & 54 & $\mathrm{Si}_{5} \mathrm{O}_{16}^{12-}$ \\
0.322 & 52 & $\mathrm{Si}_{10} \mathrm{O}_{31}^{22-}$ \\
0.333 & 50 & $\mathrm{Si}_{n} \mathrm{O}_{\mathrm{n}}^{2 \mathrm{n}-}$ \\
\hline
\end{tabular}

However, from the activation energy measurement at 50 mole percent $\mathrm{CaO}$, it was established that the planar rings of the type $\mathrm{Si}_{3} \mathrm{O}_{9}^{6-}$ and $\mathrm{Si}_{4} \mathrm{O}_{12}^{8-}$ (Fig. 3) are present at this composition. Further increase in silica causes polymerization of these rings and bigger anions of the general formula $\mathrm{Si}_{n} \mathrm{O}_{3 n+3}^{6}$ or $\mathrm{Si}_{n} \mathrm{O}_{2 n+4}^{8 .}$ may result. Out of these, $\mathrm{Si}_{n} \mathrm{O}_{2 n+3}^{(-)}$is preferable $/ 3 /$, as the $\mathrm{Si}-\mathrm{O}-\mathrm{Si}$ bond angle at this ionic species is constantly $135^{\circ}$. The discrete anions, which increase gradually in size and do not change in type, are formed by further addition of $\mathrm{SiO}_{2}$ such as

$$
\begin{aligned}
& \mathrm{Si}_{3} \mathrm{O}_{9}^{\dagger-}+3 \mathrm{SiO}_{2} \rightarrow \mathrm{Si}_{6} \mathrm{O}_{15}^{6-} \\
& \mathrm{Si}_{6} \mathrm{O}_{15}^{6}+3 \mathrm{SiO}_{2} \rightarrow \mathrm{Si}_{9} \mathrm{O}_{21}^{6-}
\end{aligned}
$$

and so on.

The idealized $\mathrm{Si}_{6} \mathrm{O}_{15}^{6-}$ ion present at 33 mole percent $\mathrm{MO}$ and essentially formed by the linking of two $\mathrm{Si}_{3} \mathrm{O}_{9}^{\epsilon-}$ rings is shown in Fig. $4 / 7 /$. The ions postulated at compositions between 10-50 mole percent of $\mathrm{MO}$ are given in Table 2.

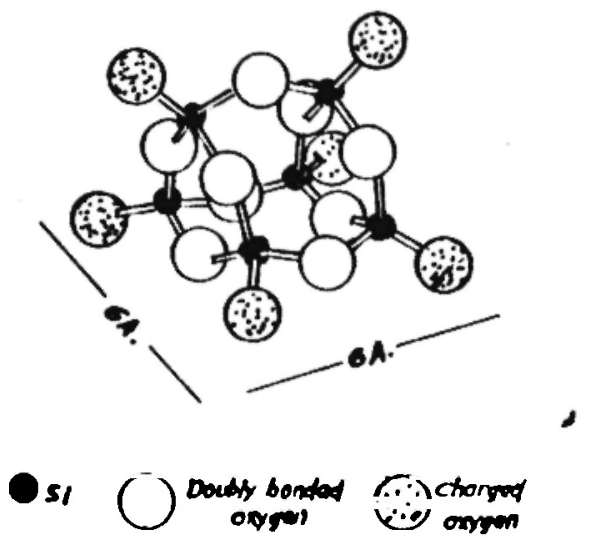

Fig. 4: Idealised $\mathrm{Si}_{6} \mathrm{O}_{15}$ lon of 33 mole percent metal oxide.
TABLE 2

ANIONS PRESENT BETWEEN 10-50 MOLE PERCENT METAL OXIDE /3/

\begin{tabular}{lccc}
\hline Composition & $\begin{array}{c}\text { Molar } \\
\text { percent } \mathrm{MO}\end{array}$ & $\begin{array}{c}\text { Discrete } \\
\text { lon }\end{array}$ & $\begin{array}{c}\text { Chain } \\
\text { length } \mathrm{A}^{\circ}\end{array}$ \\
\hline $\mathrm{SiO}_{2}+\mathrm{MO}$ & 50 & $\mathrm{Si}_{3} \mathrm{O}_{9}^{6-}$ & - \\
$2 \mathrm{SiO}_{2}+\mathrm{MO}$ & 33 & $\mathrm{Si}_{6} \mathrm{O}_{15}^{6 .}$ & 6 \\
$3 \mathrm{SiO}_{2}+\mathrm{MO}$ & 25 & $\mathrm{Si}_{9} \mathrm{O}_{21}^{-}$ & 9 \\
$4 \mathrm{SiO}_{2}+\mathrm{MO}$ & 20 & $\mathrm{Si}_{12} \mathrm{O}_{27}^{6-}$ & 12 \\
$5 \mathrm{SiO}_{2}+\mathrm{MO}$ & 16.7 & $\mathrm{Si}_{15} \mathrm{O}_{3}^{6-}$ & 15 \\
$6 \mathrm{SiO}_{2}+\mathrm{MO}$ & 14.3 & $\mathrm{Si}_{18} \mathrm{O}_{39}^{6-}$ & 18 \\
$7 \mathrm{SiO}_{2}+\mathrm{MO}$ & 12.5 & $\mathrm{Si}_{21} \mathrm{O}_{45}^{6 .}$ & 21 \\
$8 \mathrm{SiO}_{2}+\mathrm{MO}$ & 11.1 & $\mathrm{Si}_{24} \mathrm{O}_{51}^{6-}$ & 23
\end{tabular}

Thus, addition of $\mathrm{SiO}_{2}$ to 50 mole percent $\mathrm{MO}-\mathrm{SiO}_{2}$ permits the formation of discrete flow units without severing $\mathrm{Si}-\mathrm{O}$ bonds, as evidenced from the small increase of $\mathrm{E}_{p}$ up to 88 mole percent $\mathrm{SiO}_{2}$; thereafter, there is a sudden increase of $E_{\mu}$ due to the instability of the discrete anions. It is suggested by Callow /8/ that cations of the first $12 \% \mathrm{MO}$ are accommodated within the interstices of the threedimensional silica network, any further addition producing a break-up into complex anions.

In an actual melt an equilibrium mixture of two or more discrete anions may be present. Toop and Samis $/ 9,10 /$ have suggested methods to find out the most probable number of silicate anions and also $\mathrm{O}^{2-}$ ions. According to their theory, whenever two silicate anions polymerize, the resultant reaction is:

$$
20^{-} \rightarrow \mathrm{O}^{\circ}+\mathrm{O}^{2-}
$$

where $\mathrm{O}^{-}$is the singly bonded oxygen, $\mathrm{O}^{\circ}$ is the doubly bonded ion, and $\mathrm{O}^{2-}$ is the free oxygen ion. On the other hand, whenever there is a breakdown into simple anions, the resultant reaction is:

$$
\mathrm{O}^{\circ}+\mathrm{O}^{2-} \rightarrow 20^{\circ}
$$

The equilibrium constant $\mathrm{K}$ for eq. (4) is given by

$$
K=\frac{\left(O^{\circ}\right)\left(O^{2-}\right)}{(O)^{2}}
$$

and is a function of temperature and composition of the melt. Considering various factors such as valency of silicate anions and their stability with respect to size, they have given a curve which describes a relationship between the number of silicon ions per 
average anionic species and proportion of singly bonded oxygens $\left(\mathrm{O}^{\circ} / \mathrm{O}^{\circ}+\mathrm{O}^{-}+\mathrm{Si}^{4+}\right)$. With the help of this plot the probable number of silicate anions can be established, and consequently the structure of the melt can be defined.

\subsection{Interrelation between Conductance and Viscosity}

The binary liquid silicate structure has also been predicted from conductance measurements of melts /1/. The Rasch-Hinrichsen law

$$
\mathrm{K}=\mathrm{A}_{\mathrm{e}}^{-\mathrm{E}_{\mathrm{k}} / \mathrm{RT}}
$$

is obeyed for the system. The conductance is found to rise, and the energy of activation for conductance $\left(E_{k}\right)$ is found to fall with increasing metal oxide content. The electrical conductance is ionic, the current being carried predominantly by metal cations. This is in agreement with the fact that conductance increases with an increase in metal oxide content and reaches a peak with oxides of monovalent metals of small ionic radius. A comparison of $E_{k}$ and $E_{\mu}$ for the binary systems of both alkali and alkaline earth oxides shows that $E_{\mu}$ is always much greater than $E_{k}$, demonstrating that $\mu$ is determined by the movement of the large anionic silicate groups whereas conductance is related to the motion of the cations. Addition of metal oxide has a network breaking effect and, consequently, there is an increase in mobility of cations through the broken structure. Bockris et al. $/ 1 /$ used the ion-oxygen attraction model to interpret their results. They found that cations with a high ion oxygen attraction $(I>1.6)$ tend to seize oxygen ions and hold them in a particular type of packing dependent upon cation size; hence such cations, for example, $\mathrm{Si}^{4+}, \mathrm{Al}^{3+}, \mathrm{Ti}^{4+}$, are termed 'network formers'. Ions of low ion-oxygen attraction $(I<0.7)$ are unable to build a network and are called 'network modifiers'. These include the alkali and the alkaline earth metal cations, with the exception of $\mathrm{Mg}^{2+}$, which has a partial network forming tendency.

\subsection{Polycomponent Melts}

Mackenzie /11/ took viscosity measurements on ternary liquid silicate systems with silica and two metallic oxides (two alkali oxide or one alkali and one alkaline earth oxide) over the temperature range $900-1400^{\circ} \mathrm{C}$ and reported that the linear relationship between $\log \mu$ and $1 / \mathrm{T}$ still holds. The activation energy of viscous flow was found to vary between
$36-43 \mathrm{kcal} / \mathrm{mole}$. It was inferred that the mechanism of flow in binary melt containing one cation of a particular group should be identical to any polycomponent liquid silicate with two or more cations of the same group, provided that the total molar concentrations of metal oxides are equal. Similarly, a ternary melt containing cations of different groups may be viewed as an ideal mixture of two binary melts. On this basis the activation energy of viscous flow can be determined from the relationship

$$
\mathrm{E}_{\mathrm{u}}=\mathrm{n}_{\mathrm{A}}\left(\mathrm{E}_{\mathrm{A}}\right)_{\mathrm{x}}+\mathrm{n}_{\mathrm{B}}\left(\mathrm{E}_{\mathrm{B}}\right)_{\mathrm{x}}
$$

where $n_{A}$ and $n_{B}$ are the mole fractions of the two metal oxides, and $\left(E_{A}\right)_{x}$ and $\left(E_{B}\right)_{x}$ are activation energies for the two groups at the total metal oxide concentrations, respectively. He found good agreement between the calculated values according to eq. (8) and the observed values of the polycomponent systems considered. From this he concluded that the discrete ion theory based on binary systems is applicable to polycomponent melts and that the mechanism of flow is identical at the same molar concentrations of silica. He also suggested an empirical relationship to calculate the viscosity for each group,

$$
\log \mu-(\alpha+\beta C)+\frac{\gamma+\delta C}{2.303 R T}
$$

where $\alpha, \beta, \gamma$ and $\delta$ are constants and $C$ is the total molar concentration of metal oxides. The values of these constants for Group I and Group II metal oxides were determined. Eq. (10) was then used to calculate the viscosity of the polycomponent system:

$$
\mu=\mathrm{n}_{\mathrm{A}}\left(\mu_{\mathrm{A}}\right)_{\mathrm{C}}+\mathrm{n}_{\mathrm{B}}\left(\mu_{\mathrm{B}}\right)_{\mathrm{C}}
$$

Here also he found good agreement between calculated and experimental values.

\subsection{Role of Ionic Interaction on Viscosity}

Based on a reaction rate phenomenon, the expression for viscosity is given as $/ 6,12 /$ :

$$
\mu=\frac{N h}{V} e^{\frac{-\Delta S^{*}}{R}} e^{\frac{\Delta H^{*}}{R T}}
$$

where $\mathrm{N}$ is Avogadro's number, $\mathrm{V}$ is molar volume of flow units (chains or discrete anions), h is Planck's constant, $\Delta S^{*}$ is the entropy of activation, and $\Delta H^{*}$ is the heat of activation (same as activation energy for viscous flow). 
$\Delta \mathrm{H}^{*}$ depends on the size of the average flow unit and the strength and number of various coulombic interactions between the flow unit and its surrounding species.

$\Delta \mathrm{H}^{*}$ rises with an increase in flow unit size. The importance of coulombic interactions in binary silicate melts may be the attraction between the singly bonded oxygens of the flow units and free metallic ions $\left(\mathrm{M}^{++}-\mathrm{O}^{-}\right.$interaction) and the repulsion between two singly bonded oxygens of different flow units $\left(\mathrm{O}^{*}-\mathrm{O}^{-}\right.$interaction $) . \Delta \mathrm{H}^{*}$ increases with a higher number of attractions and a lower number of repulsions. These interactions also affect the values of $\Delta S^{*}$ which rises with an increasing number of attractions and decreasing number of repulsions.

As the metal oxide percentage is increased, smaller flow units form, and therefore the molar volume decreases. Calculations based on actual viscosity measurement have shown that $\Delta \mathrm{H}^{*}$ and $\mathrm{S}^{*}$ also decrease with an increase in metal oxide contents. A decrease in $\Delta S^{*}$ suggests that $\mathrm{O}^{*}-\mathrm{O}^{-}$interactions tend to be more dominating than $\mathrm{M}^{++}-\mathrm{O}^{-}$ interactions. A decrease in $\Delta \mathrm{H}^{*}$ is probably caused by the joint effect of a decrease in flow unit size and increased effectiveness of $\mathrm{O}^{-}-\mathrm{O}^{-}$interaction. From eq. (11) it is apparent that variation in $\Delta S^{*}$ and $V$ tend to counteract the effect due to variation in $\Delta \mathrm{H}^{*}$ However, since the viscosity continuously falls with increasing addition of metal oxide, it is obvious that the latter effect is always more dominant than the other two. It is important to note here that, because of relatively higher and higher oxygen requirements of the smaller flow units, the progressive additions of metal oxide are increasingly less effective in reducing the flow unit size. This explains why with increasing metal oxide percent, viscosity is lowered at an everdecreasing rate.

The contribution of different oxides in reducing the viscosity can be discussed in light of the above phenomenon. Due to the bridging effect of alkaline earth cations, the $\mathrm{O}^{-}-\mathrm{O}^{-}$interaction is not as effective as in alkali metal cations. Hence, addition of a given amount of alkali metal oxide results in a greater reduction in viscosity than occurs for an alkaline earth addition of the same amount.

\subsection{Complex Melts}

Most industrial silicate slags contain alumina, magnesia, and calcium fluoride as well as lime and silica. Hence the way in which these substances enter into silicate melts is of interest.
When alumina is present in the melt, it is considered that $\mathrm{Al}^{3+}$ adopts a four-fold coordination with oxygen and substitutes for silicon in the linked tetrahedral structure $/ 13,14 /$, provided that the cation/ anion ratio is also adjusted in order to preserve electroneutrality. This is possible when the molar ratio of $\mathrm{Al}_{2} \mathrm{O}_{3} / \mathrm{CaO}$ is less than one, i.e., sufficient basic oxide is present in the melt. In such cases the melt contains $\mathrm{SiO}_{4}^{1}$ and $\mathrm{AlO}_{4}^{--}$ions. When this ratio exceeds one, there will not be sufficient oxygen for the formation of $\mathrm{AlO}_{4}^{5-}$ tetrahedra together with the tetrahedral silicate anionic units, and hence aluminium in these melts will have six-fold coordination with oxygen and will enter the interstices in the structure /15/. This will contribute to the disintegration of complex alumino-silicate anions. Machin and Hanna /14/ have suggested that when the basic oxides present are less than enough to furnish the required oxygen, polymeric ions such as those given below are formed:

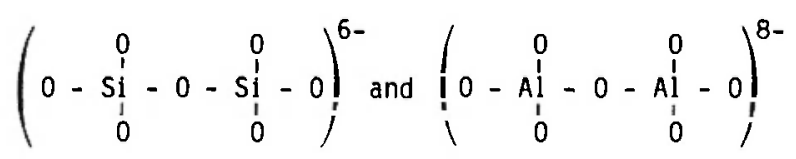

The probability of a high percentage of these polymeric ions would be raised by increasing percentage of alumina and/or silica and lowered by increasing percentage of lime and/or magnesia. They have given a relationship to calculate the degree of polymerization or the ratio of shared to unshared oxygen atoms, $R$. This is expressed as:

$$
R=(4-\mathrm{N}) / 2(\mathrm{~N}-2)
$$

where $\mathrm{N}$ is the oxygen/silicon ratio $(\mathrm{O} / \mathrm{Si}$ ratio is the number of oxygen atoms/the number of silicon or aluminium atoms present in the flow unit; $\mathrm{Al}$ atoms can be counted as equivalent to silicon atoms).

From the viscosity study of the system $\mathrm{CaO}-\mathrm{SiO}_{2}$ $\mathrm{Al}_{2} \mathrm{O}_{3}$ within the temperature range of $1450-2000^{\circ} \mathrm{C}$, Kozakevitch /13/ found that some of the isokoms (lines of equal viscosity) for the above melts reach minima when the molar ratio $\mathrm{Al}_{2} \mathrm{O}_{3} / \mathrm{CaO}$ is about 1 ; i.e., for a given silica concentration viscosity increases as $\mathrm{CaO}$ is replaced by $\mathrm{Al}_{2} \mathrm{O}_{3}$ until the molar ratio $\mathrm{Al}_{2} \mathrm{O}_{3} / \mathrm{CaO}$ is about 1 . Above this ratio an increase in alumina content decreases the viscosity. So when the molar ratio $\mathrm{Al}_{2} \mathrm{O}_{3} / \mathrm{CaO}<1$, i.e., in neutral and basic slags, alumina and silica behave similarly. In other words under such conditions the tetrahedral Al$\mathrm{O}$ coordination is isomorphous to that of $\mathrm{Si}-\mathrm{O}$ coor- 

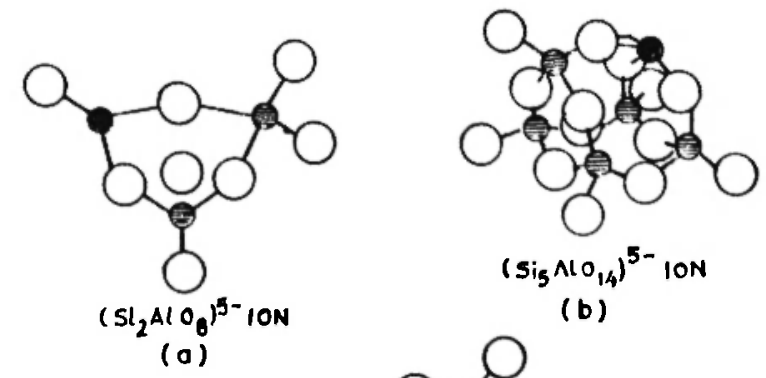

(b)
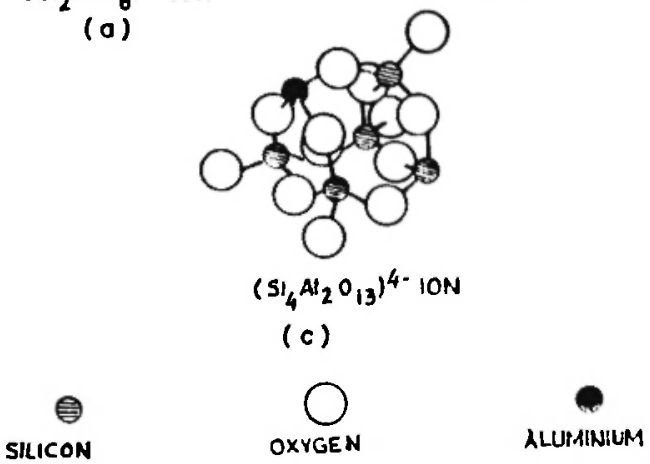

Fig. 5: Discrete anions in liquid alumina silicates

dination, i.e., $\mathrm{Al}$ and $\mathrm{Si}$ will occupy similar sites in the lattice so that the total network forming ions will be $\mathrm{Al}+\mathrm{Si}$. However, at high molar $\mathrm{Al}_{2} \mathrm{O}_{3} / \mathrm{CaO}$ ratios and high silica concentrations, $\mathrm{Al}_{2} \mathrm{O}_{3}$ behaves as a network modifier and hence decreases the viscosity. This is consistent with the generally accepted view that alumina is amphoteric, acting as a base in acid melts and as an acid in basic melts.

Seshadri and Gupta /16/ have, however, proposed an alternative model for alumino-silicates. By comparing the viscosity data for the binary $\mathrm{CaO}-\mathrm{SiO}_{2}$ system and the ternary $\mathrm{CaO}-\mathrm{SiO}_{2}-\mathrm{Al}_{2} \mathrm{O}_{3}$ system on the basis of average anion size and charge, they have demonstrated that the four-fold coordination model for $\mathrm{Al}^{3+}$ does not satisfactorily explain the viscosity results. In the new model proposed, aluminium, having a valency of three, is considered to be bonded to only three oxygens, as illustrated in Fig. 5. This predicts a variable coordination number of $\mathrm{Al}^{3+}$ in the melt because a high level of disorder persists in the liquid state (i.e., different $\mathrm{Al}^{3+}$ ions may have different coordination numbers depending on the neighbours present). This is strongly supported by $\mathrm{Al}$-nuclear resonance studies made on $\mathrm{CaO}-\mathrm{SiO}_{2}-$ $\mathrm{Al}_{2} \mathrm{O}_{3}$ glasses $/ 17 /$ which indicate that the oxygen coordination sphere of the aluminium is more or less statistically distorted. This should not have been the case in four-fold coordination of aluminium where it is completely shielded by four surrounding oxygens. Based on this it is suggested by Gupta and Seshardri $/ 12 /$ that in alumino-silicate melts $\mathrm{Al}^{3+}-\mathrm{O}^{-}$type of interactions are also present besides $\mathrm{Ca}^{++}-\mathrm{O}^{-}$and $\mathrm{O}^{-}$ - $\mathrm{O}^{-}$interactions. This interaction will increase the activation energy of viscous flow. Depending on the $\mathrm{Al}_{2} \mathrm{O}_{3} / \mathrm{SiO}_{2}$ ratio, i.e., the $\mathrm{Al} / \mathrm{Al}+\mathrm{Si}$ ratio, the proportion of $\mathrm{Al}^{3+}-\mathrm{O}^{-}$interaction will vary from melt to melt; hence flow unit size alone cannot be taken as a measure of viscosity. It follows that the variation of viscosity in alumino-silicate melts may be described as: (1) for constant average flow unit mass, viscosity should rise with the increase in $\mathrm{Al} / \mathrm{Al}+\mathrm{Si}$ ratio, and, consequently, (2) for the same $\mathrm{Al} / \mathrm{Al}+\mathrm{Si}$ ratio, viscosity should rise with the increase in average flow unit mass.

Turkdogan and Bills /18/ have suggested an empirical formula to find the silica equivalence of alumina at high $\mathrm{Al}_{2} \mathrm{O}_{3} / \mathrm{CaO}$ ratios and high silica concentrations from the viscosity data of $\mathrm{CaO}-\mathrm{SiO}_{2}$ and $\mathrm{CaO}-\mathrm{SiO}_{2}-\mathrm{Al}_{2} \mathrm{O}_{3}$ melts. For a given temperature and viscosity the silica equivalence of alumina( $\mathrm{Na}$ ) is given by the difference between silica concentration of binary and ternary melts:

$$
\mathrm{Na}=\mathrm{N} \mathrm{SiO}_{2} \text { (binary) }-\mathrm{N} \mathrm{SiO}_{2} \text { (ternary) }
$$

The calculated values of $\mathrm{Na}$ from the viscosity data of Bockris and Lowe /6/ and Kozakevitch /13/ were plotted and are reproduced in Fig. 6. It can be seen from the figure that $\mathrm{Na}$ is related to the molar ratio $\mathrm{Al}_{2} \mathrm{O}_{3} / \mathrm{CaO}$ and alumina concentration within the composition range studied by Kozakevitch. It should

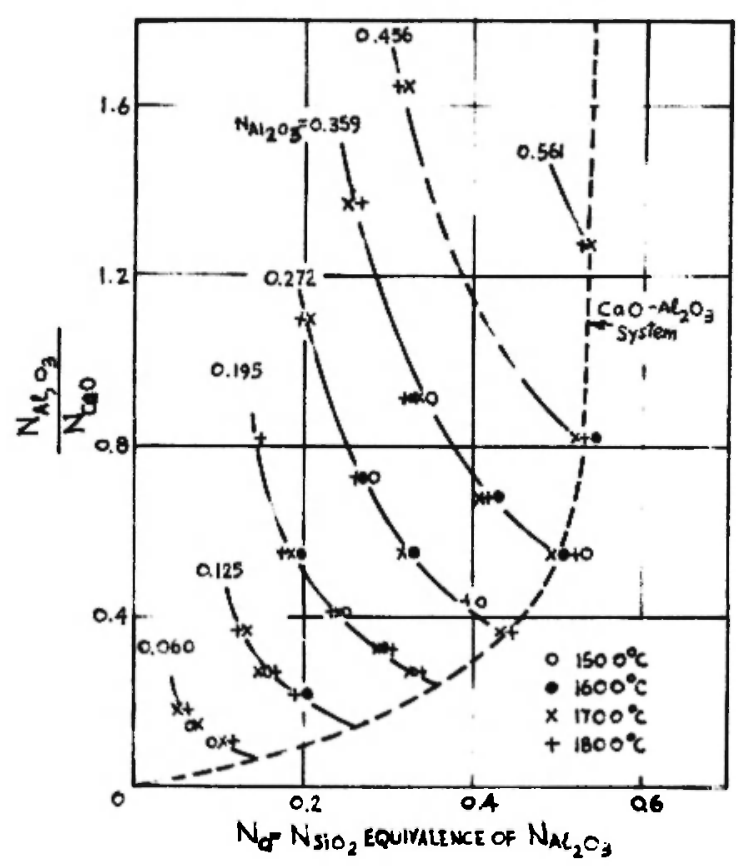

Fig. 6: Silica equivalence of alumina, $\mathrm{Na}$, related to molar $\mathrm{Al}_{2} \mathrm{O}_{3} / \mathrm{CaO}$ ratio and molar alumina concentration in $\mathrm{CaO}-\mathrm{SiO}_{2}-\mathrm{Al}_{2} \mathrm{O}_{3}$ melts. 
be further noted that the relationship is independent of temperature within the range $1500-1800^{\circ} \mathrm{C}$. The curve shown by the dotted line corresponds to the binary $\mathrm{CaO}-\mathrm{Al}_{2} \mathrm{O}_{3}$ system. A more usable form of this diagram is shown in Fig. 7, where mole fraction of alumina is plotted against $\mathrm{Na}$ for several molar $\mathrm{Al}_{2} \mathrm{O}_{3} / \mathrm{CaO}$ ratios.

The slags of more practical interest are $\mathrm{CaO}$ $\mathrm{MgO}-\mathrm{Al}_{2} \mathrm{O}_{3}-\mathrm{SiO}_{2}$ type quartenary slags. Machin, Hanna, and Yee were the pioneer workers to systematically measure the viscosity of these systems over a wide range of compositions in platinum crucibles $/ 14,19-21 /$. They plotted the isokoms at temperatures of $1350,1400,1450$ and $1500^{\circ} \mathrm{C}$ and observed that some of the isokoms were approximately parallel to the lines along which the acid/base ratios (moles of $\mathrm{SiO}_{2}+$ moles of $\mathrm{Al}_{2} \mathrm{O}_{3} /$ moles of $\mathrm{CaO}+$ moles of $\mathrm{MgO}$ ) are constant, especially so in the

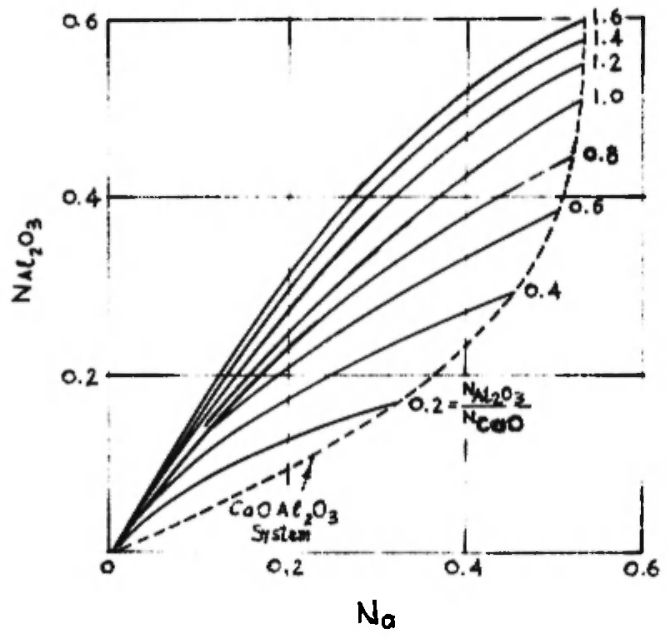

Fig. 7: Silica equivalence of alumina related to molar alumina concentrations and molar $\mathrm{Al}_{2} \mathrm{O}_{3} / \mathrm{CaO}$ ratio in $\mathrm{CaO}-\mathrm{SiO}_{2}-\mathrm{Al}_{2} \mathrm{O}_{3}$ melts.

system with $40 \% \mathrm{SiO}_{2}$. The $\mathrm{S}$-shaped isokoms show minimum change of viscosity with variation of alumina content near the ends. In the region of $60 \%$ or more silica, alumina appears to be less effective in increasing the viscosity. This is also the case in slags with $40 \%$ or less silica content. In the area between these limits the effect of alumina on the viscosity of the melt is nearly as great as that of silica. It was also observed by them that the viscosity at constant lime content decreases with increasing magnesia content at constant silica content. When both silica and alumina remain constant, the rise of magnesia decreases viscosity only to a slight degree for quantities of magnesia up to $10 \mathrm{wt} \%$. As magnesia is increased to $20 \mathrm{wt} \%$, the decrease in viscosity for the same silica and alumina value is more marked. Similar findings have been reported by Yakushev et al. /22/ in a synthetic slag of $40-48 \% \mathrm{CaO}, 17.5-40 \% \mathrm{Al}_{2} \mathrm{O}_{3}$, $15-30 \% \mathrm{SiO}_{2}$, and $4-12 \% \mathrm{MgO}$.

The rate of change of viscosity with respect to variation of lime and alumina content is less as the magnesia content increases. Advantage may be taken of this fact to minimize viscosity variation of slag in iron blast furnace operation.

In this connection it may be seen from the results of Bockris et al. /3/ and Mackenzie /11/ that alkaline earth oxides are interchangeable in their effects on the viscosity of binary melts, and similar behaviour is therefore expected to hold for the quartenary melts. This has been illustrated graphically by Turkdogan and Bills /18/ (Fig. 8). It can be observed from the figure that lime and magnesia are replaceable on the molar basis and that the derivation of silica equivalence of alumina ( $\mathrm{Na})$ from Fig. 7 is not affected by the presence of magnesia. The plot of Fig. 8 demonstrates that the data on binary, ternary, and quartenary melts could be represented by a

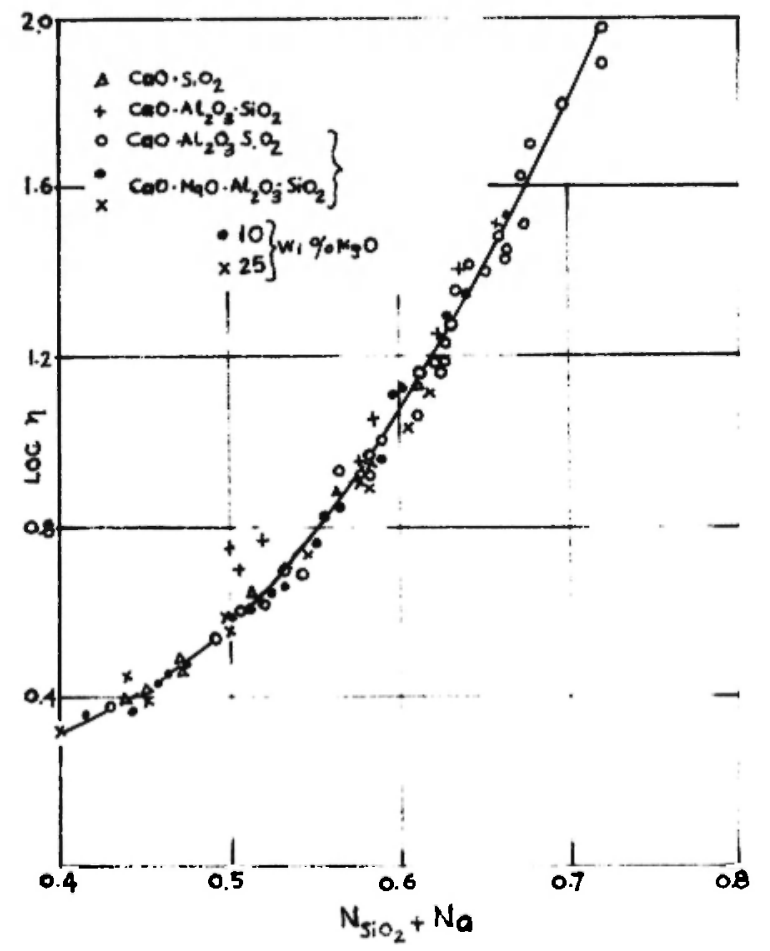

Fig. 8: Variation of viscosity with composition of $\mathrm{CaO}$ $\mathrm{MgO}-\mathrm{Al}_{2} \mathrm{O}_{3}-\mathrm{SiO}_{2}$ melts at $1500^{\circ} \mathrm{C}$. 
single curve with only a small scatter. However, the viscosity values of the slags may differ by as much as $20 \%$ even for the same $\mathrm{Na}+\mathrm{N} \mathrm{SiO}_{2}$ value so that the usefulness of this curve may be limited.

Kawahara et al. /23/ have suggested, however, that $\mathrm{MgO}$ is amphoteric in nature, e.g., in the $\mathrm{CaO}$ $\mathrm{SiO}_{2}-\mathrm{MgO}$ system, $\mathrm{MgO}$ behaves similarly to $\mathrm{CaO}$, but in the $\mathrm{Na}_{2} \mathrm{O}-\mathrm{SiO}_{2}-\mathrm{MgO}$ system, it acts as an acidic oxide. Like all amphoteric oxides, the strength of $\mathrm{MgO}$ as a basic oxide increases with decreasing basicity of the melt and as a function of its content in the melt.

\subsection{Calcium Fluoride Addition to Silicate Melts}

The discrete anion model still holds good for reduction of viscosity caused by adding calcium fluoride to silicate melts. In binary silicates incorporation of fluoride is only possible at compositions containing more than about $12 \% \mathrm{M}_{\mathrm{x}} \mathrm{O}_{\mathrm{y}}$ (otherwise separation of a pure fluoride phase occurs $/ 6 /$ ). It is suggested that the $\mathrm{F}^{-}$ions replace the divalent $\mathrm{O}^{2-}$ ions in the silicate structure $/ 24 /$. The depolymerization action of the fluoride is explained by the reactions of the type shown in Fig. 9.

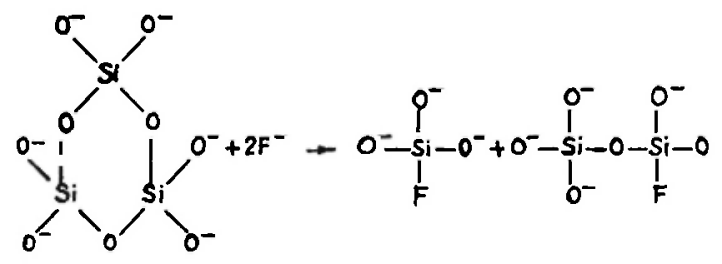

Fig. 9: Depolymerisation of silicate structure by addition of fluorides.

Kozakevitch $/ 25 /$ also found that calcium fluoride was much more effective on a molar basis than lime in lowering the viscosity of $\mathrm{CaO}-\mathrm{Al}_{2} \mathrm{O}_{3}-\mathrm{SiO}_{2}$ melts. $\mathrm{He}$ postulated that if calcium fluoride enters the siliconoxygen lattice of the slag by breaking silicon-oxygen bonds in a manner similar to calcium oxide, then one mole of $\mathrm{CaF}_{2}$ should be equivalent to two moles of lime in its effect on viscosity (Fig. 10). However, the effect of calcium fluoride was found to be much greater than that expected from the above theory. In a viscosity measurement investigation, Bills /26/ took two $\mathrm{CaO}-\mathrm{SiO}_{2}-\mathrm{Al}_{2} \mathrm{O}_{3}$ slags $(40: 40: 20$ and 35:50:15) and added $2 \%$ and $9.5 \% \mathrm{CaF}_{2}$ to the first slag and $5 \%$ and $15 \% \mathrm{CaF}_{2}$ to the second one. It was discovered that addition of $\mathrm{CaF}_{2}$ decreased the viscosity of the melts considerably and that this effect (a)

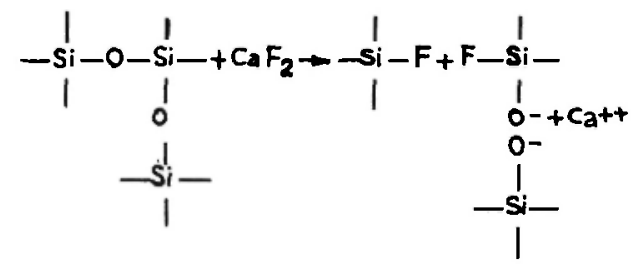

(b)

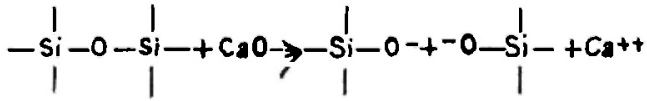

Fig. 10: Comparison of the effect of calcium oxide with hypothetical effect of calcium fluoride on silicate network.

was much greater at lower temperatures. From the viscosity observation he suggested that it was unlikely that $\mathrm{CaF}_{2}$ breaks the $\mathrm{Si}-\mathrm{O}$ bonds with consequent reduction in the size of the silicate flow unit. However, he agreed with Baak's postulation /27/ that $\mathrm{CaF}_{2}$ ionizes in such a way as to act as a solvating agent for the large silicate anions which are bound together by electrostatic forces. When $\mathrm{CaF}_{2}$ is added, it reacts with $\mathrm{Ca}^{++}$ions to form two $\mathrm{CaF}^{+}$ions which attach themselves to singly bonded oxygens of the flow units, hence decreasing the attractive interaction between the singly bonded oxygens $\left(\mathrm{O}^{-}\right)$and calcium ions. This action is known as the solvating effect of unstable $\mathrm{CaF}^{+}$ions on the silicate anions as shown in Fig. 11. This results in a considerable lowering of the viscosity.

If this theory is correct, the magnitude of the effect of $\mathrm{CaF}_{2}$ on the decrease in viscosity, especially at low temperature, indicates that, normally, the flow resistance due to ionic interactions is just as important as the size of the silicate flow units themselves. It is due to this interaction effect that viscosity in binary alkaline earth silicates is so much higher in value than in corresponding alkali silicates where this electrostatic binding of silicate anions cannot take

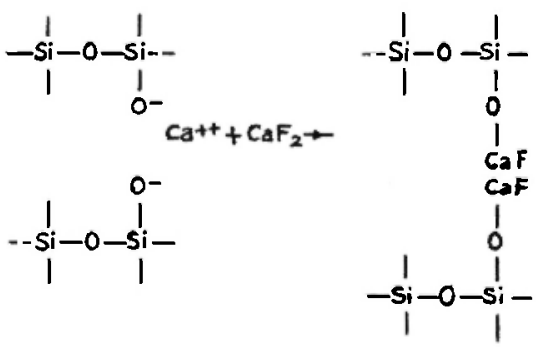

Fig. 11: Hypothetical solvating effect of addition of $\mathrm{CaF}_{2}$ to silicate melt. 
place due to the absence of multivalent cations. The above mechanism suggested by Baak is supported by activity coefficient curves of $\mathrm{CaSiO}_{3}-\mathrm{CaF}_{2}$ systems /28/ and conductivity measurements on $\mathrm{CaO}-\mathrm{SiO}_{2}-$ $\mathrm{Al}_{2} \mathrm{O}_{3}-\mathrm{CaF}_{2}$ melts $/ 29 /$. The mechanism was also supported by Gupta and Seshadri /30/ who determined viscosity measurements of alumino-silicate slags containing $20 \%, 25 \%$, and $30 \% \mathrm{Al}_{2} \mathrm{O}_{3}$, each with $5 \%, 10 \%$, and $15 \% \mathrm{CaF}_{2}$ additions. They observed that, for the same weight percent of $\mathrm{CaF}_{2}$ addition, the percentage reduction in viscosity at a given temperature is almost independent of alumina content of the melt and that between 5 and $10 \mathrm{wt} \%$ $\mathrm{CaF}_{2}$, the ability of alumina to reduce viscosity is comparatively low over the entire range investigated. They explained their observations assuming a threefold coordination for aluminium and calculating the number of flow units per $10^{5} \mathrm{~g}$ of slag.

Kato and Minowa /31/ added different fluorides to alumino-silicate melts and observed that the effect of the fluorides in reducing the viscosity is ranked as $\mathrm{CaF}_{2}>\mathrm{MgF}_{2}>\mathrm{AlF}_{3}>\mathrm{NaF}$. For the $\mathrm{CaO}-\mathrm{SiO}_{2}-$ $\mathrm{Al}_{2} \mathrm{O}_{3}-\mathrm{MgO}$ system, it is also reported that $6 \mathrm{wt} \%$ addition of $\mathrm{CaF}_{2}$ approximately halves the viscosity of the quartenary slag without calcium fluoride $/ 5 /$.

\subsection{Role of Other Constituents}

1.8.1. Slags with iron oxides. From a viscosity study of the $\mathrm{CaO}-\mathrm{SiO}_{2}-\mathrm{FeO}$ system, Kozakevitch /32,33/ found that above 35 mole percent $\mathrm{SiO}_{2}$ viscosity depends on $\mathrm{SiO}_{2}$ content and is virtually independent of $\mathrm{FeO}$ and $\mathrm{CaO}$ contents due to the predominance of silicate anions above this composition. In another study Bills /26/ inferred that a gradual addition of $\mathrm{FeO}$ up to $15 \mathrm{wt} \%$ decreases the viscosity of $\mathrm{CaO}-\mathrm{MgO}-\mathrm{Al}_{2} \mathrm{O}_{3}-\mathrm{SiO}_{2}$ quartenary slags and that the effect of larger additions of $\mathrm{FeO}$ is more pronounced at high temperatures. At lower $\mathrm{FeO}$ contents than $15 \mathrm{wt} \%$, the effect of addition of more $\mathrm{FeO}$ is equivalent on a molar basis to the addition of $\mathrm{MgO}$, but at higher $\mathrm{FeO}$ content it is not valid. $\mathrm{He}$ suggested that the reason might be due to the difference in electrostatic binding forces which bind $\mathrm{Fe}^{2+}$ and $\mathrm{Mg}^{2+}$ cations to silicate anions. He measured the energy of activation of viscous flow, which was found to decrease slightly with an increase in temperature but was fairly constant for all slags (45 kcal/mole).

The iron oxide, when added to silicate melts, can break up the silicate anions by providing free oxygen ions according to the equations /34/:

$$
\begin{aligned}
& \mathrm{FeO}=\mathrm{Fe}^{2+}+\mathrm{O}^{2-} \\
& \mathrm{Fe}_{2} \mathrm{O}_{3}=2 \mathrm{FeO}^{+}+\mathrm{O}^{2-}
\end{aligned}
$$

In acid slags the addition of iron oxide decreases the viscosity more than in basic slags, as iron oxide in acid slag can break up the silicate anions more effectively than in basic slags. In basic slags, however, the trivalent iron ion exists to a larger extent in the form of ferrite anions which are not able to provide free oxygen ions. Moreover, in basic slags, even if iron oxide content is low, the silicate anion is of smaller size and hence viscosity is low. Consequently, the addition of iron oxide has little effect in lowering the viscosity in basic slags. Just as the smallest structural unit of the silicate anion is $\mathrm{SiO}_{4}^{-}$, like $\mathrm{Fe}_{2} \mathrm{O}_{4}^{2-}$ ions are in the ferrite anion, they are hardly liable to thermal dissociation without complete structural change. Hence viscosity of acid slag is strongly dependent on temperature at low iron oxide content and weakly so at high iron oxide content, whereas viscosity of basic slag is weakly dependent on temperature at all iron oxide contents.

1.8.2. Slags with barium oxide. Bills /26/ replaced part of the lime in the $\mathrm{CaO}-\mathrm{SiO}_{2}-\mathrm{FeO}$ system with $\mathrm{BaO}$ and observed that, for a given temperature, the effect of this substitution on a weight percent basis is to raise the viscosity of the melt, as a result of the replacement of $\mathrm{CaO}$ by $\mathrm{BaO}$, which leads to a lower mole fraction of alkaline earth oxide and, consequently, to a higher mole fraction of silica (mol wts of $\mathrm{CaO}$ and $\mathrm{BaO}$ are 56.1 and 153.4 , respectively).

A comparison of binary data of $\mathrm{CaO}-\mathrm{SiO}_{2}, \mathrm{FeO}-$ $\mathrm{SiO}_{2}, \mathrm{BaO}-\mathrm{SiO}_{2}$, and $\mathrm{MgO}-\mathrm{SiO}_{2}$ systems reveals that at $1450^{\circ} \mathrm{C} \mathrm{FeO}-\mathrm{SiO}_{2}$ melts have very low viscosity compared to corresponding ones in the $\mathrm{CaO}-\mathrm{SiO}_{2}$ system. This may be due to the existence of a stronger bond between the metal cation and silicate anion in the latter system. However, at $1600^{\circ} \mathrm{C}$ there is less difference in viscosity of the $\mathrm{CaO}-\mathrm{SiO}_{2}, \mathrm{BaO}-\mathrm{SiO}_{2}$, and $\mathrm{MgO}-\mathrm{SiO}_{2}$ systems, because at higher temperatures the bonding effect is less.

1.8.3. Minor constituents. Nesterenko et al. /35/ measured the viscosity of the $\mathrm{CaO}-\mathrm{MgO}-\mathrm{SiO}_{2}-5 \%$ $\mathrm{Al}_{2} \mathrm{O}_{3}$ system with additions of $2 \%$ sulphur, $1 \% \mathrm{MnO}$, $1 \% \mathrm{FeO}$, and $0.5 \% \mathrm{~K}_{2} \mathrm{O}$ and found lower viscosities due to these additions. They also established that, at a given temperature, the range of slags with a mini- 
mum viscosity corresponds to the slags of maximum conductivity.

\subsection{Effect of Temperature on Viscosity}

From eq. (2) it is clear that the viscosity of silicate melts decreases exponentially with rise in temperature. However, the plot of $\log \mu$ vs $1 / T$ may or may not be linear, as discussed earlier, taking structural effect into consideration. When the temperature of the melt is increased, one or both of the following two phenomena may take place: (1) weakening of the ionic bonds between cations and discrete anions, (2) gradual breakdown of the discrete anions to smaller flow units. If the first occurs, the activation energy of viscous flow remains constant within the temperature range. If the second occurs, there is a change of activation energy with a change in temperature.

\section{VISCOSITY MEASUREMENT OF SOME INDUSTRIAL SLAGS}

A large volume of literature is available on the viscosity measurement of industrial slags such as blast furnace, steel making, high titania, etc. Salient features of these studies will be presented here appropriate to the above discussions on melt structure.

\subsection{Blast Furnace Slags}

Blast furnace slag contains $\mathrm{CaO}, \mathrm{SiO}_{2}, \mathrm{Al}_{2} \mathrm{O}_{3}$, and $\mathrm{MgO}$ as major constituents, with $\mathrm{MnO}, \mathrm{FeO}, \mathrm{CaS}$, and sometimes $\mathrm{TiO}_{2}$ as minor constituents. The amount of basic oxides in the blast furnace slag is expressed as $\mathrm{CaO} / \mathrm{SiO}_{2}$ or the amount of basic oxides divided by the amount of acid oxides. Alumina, depending on the slag composition, may behave as an amphoteric oxide in these slags, as discussed earlier.

From the viscosity measurement of industrial blast furnace slags with a wide composition range, it has been observed $/ 36-41 /$ that the viscosity variation with change of composition is complicated. Nevertheless, all the investigators agree that viscosity variation with a $\mathrm{CaO} / \mathrm{SiO}_{2}$ ratio depends on the $\mathrm{MgO}$ level in the slag; the higher the $\mathrm{MgO}$ content, the lower the desired $\mathrm{CaO} / \mathrm{SiO}_{2}$ ratio for optimum viscosity. Further, they agree that a high $\mathrm{CaO} / \mathrm{SiO}_{2}$ ratio combined with a high $\mathrm{MgO}$ content in the slag results in "short" slags. It has also been reported that high alumina blast furnace slags $\left(20-34 \% \quad \mathrm{Al}_{2} \mathrm{O}_{3}\right)$ show erratic viscosity variation due to the change of the
$\mathrm{Al} / \mathrm{Si}$ ratio because, when the $\mathrm{Al}_{2} \mathrm{O}_{3}$ content is constant, the higher $\mathrm{CaO} / \mathrm{SiO}_{2}$ ratio increases the $\mathrm{Al} / \mathrm{Si}$ ratio; and, as discussed earlier, the former decreases the viscosity whilst the latter increases it.

Some investigations have been carried out on the liquidus temperature of blast furnace slags /42-44/ because the low liquidus temperature of a slag of given composition results in a high degree of superheat and hence low viscosity at the operating temperature. Fine and Arac /42/ utilized a statistical relationship to determine the variation of liquidus temperature of the synthetic slag with $10 \% \quad \mathrm{Al}_{2} \mathrm{O}_{3}$ and the ratio, wt $\%(\mathrm{CaO}+\mathrm{MgO}) / \mathrm{wt} \%\left(\mathrm{SiO}_{2}+\mathrm{Al}_{2} \mathrm{O}_{3}\right)$, ranging from $0.94-1.13$, with the addition of $\mathrm{MnO}$, $\mathrm{FeO}, \mathrm{Na}_{2} \mathrm{O}$, and $\mathrm{TiO}_{2}$. The change of liquidus temperature is given by

$$
\begin{aligned}
\Delta \mathrm{T}= & -19\left(\mathrm{wt} \% \mathrm{Na}_{2} \mathrm{O}\right)-8(\mathrm{wt} \% \mathrm{FeO}+ \\
& \text { wt } \% \mathrm{MnO})+\mathrm{b}\left(\mathrm{wt} \% \mathrm{TiO}_{2}\right) \pm 3^{\circ} \mathrm{K}
\end{aligned}
$$

where $b$ has two values, 10 and 20 , for the two slag compositions investigated. As the liquidus temperature depends on the basicity ratio, $\mathrm{Al}_{2} \mathrm{O}_{3}$ and $\mathrm{MgO}$ contents, in a complicated way, Singh et al. /43/ plotted the liquidus temperature vs $\mathrm{MgO}$ wt percent in the slag for various basicities and $\mathrm{Al}_{2} \mathrm{O}_{3}$ contents. From their plots it is observed that for a high basicity ratio (1.5), there is only one value of $\mathrm{MgO}$ giving the lowest liquidus temperature, but for low basicity ratios, the liquidus temperature remains constant for a wide range of $\mathrm{MgO}$ contents.

\subsection{Blast Furnace Slags with Titanium Oxides}

Titaniferrous ores are also sometimes smelted in the blast furnace and are said to cause problems such as accretions, scaffolds, hearth cloggings, and high fuel consumption /45/. A few investigations have been carried out to discover the role of $\mathrm{TiO}_{2}, \mathrm{Ti}_{2} \mathrm{O}_{3}$, and TiO on the liquidus temperature and viscosity of slags $/ 46-54 /$. It is commonly agreed that all oxides of titanium up to a total amount of $10 \mathrm{wt} \%$ are effective in reducing the viscosity when the slag is slightly acidic, so long as titanium carbide is not formed. It is suggested that thickening of slag in graphite containers may be due to a reduction of $\mathrm{TiO}_{2}$ by carbon leading to a consequent depletion of oxygen ions. Hence, to that end, adding $\mathrm{TiO}_{2}$ decreases viscosity by furnishing additional oxygen. From the relationship of $E_{p}$ vs weight percent of added titanium oxide, Handfield et al. /53/ suggested that $\mathrm{Ti}_{2} \mathrm{O}_{3}$ is much more effective as a network modifier 
than $\mathrm{TiO}_{2}$. The property of "shortness" of the slag is also observed $/ 54 /$ in titania bearing slags when $\mathrm{Al}_{2} \mathrm{O}_{3}$ exceeds $23 \mathrm{wt} \%$ and $\mathrm{MgO}$ exceeds $16 \mathrm{wt} \%$, with $\mathrm{CaO}+\mathrm{MgO} / \mathrm{SiO}_{2}+\mathrm{Al}_{2} \mathrm{O}_{3}$ exceeding 0.95 .

\subsection{High Titania Slags}

Viscosity measurement of industrial titania slags (68$80 \% \mathrm{TiO}_{2}$ and $3-15 \% \mathrm{FeO}$ ) indicate that once the slags are completely molten, they are characterized by a viscosity of only $30 \mathrm{cps}$, which remains fairly constant with further increase in temperature $/ 52,55 /$. Hence it was suggested that these melts are structurally different from polymerizing melts and, in the main, are semiconductors. This supposition is supported by electrical resistivity measurements of these slags, which show that they have much lower electrical resistivity than siliceous slags $/ 56 /$. The specific conductivity of these melts is so high /57,58/ (30$200 \mathrm{oh}^{-1} \mathrm{~cm}^{-1}$ in comparison to $5 \mathrm{ohm}^{-1} \mathrm{~cm}^{-1}$ for ionic melts) that the melt may be ionic-electronic rather than purely ionic. Reznichenko /57/ has postulated that molten high $\mathrm{TiO}_{2}$ slags consist mainly of anions of the type $\mathrm{TiO}_{6}^{8-}$ based on the fact that the $\mathrm{TiO}_{6}$ octahedron is the basic structural unit with solid anosovite. His hypothesis that the same basic structural unit is found in both solid and molten slags can account for the ease of crystallization of the melt, supported by the fact that nonpolymerized ionic melts are very fluid. However, his suggestion is not compatible with the high electrical conductivity of the sample and its strong dependence on composition. For this reason it is unlikely that $\mathrm{TiO}_{5}^{8-}$ anions are the basic structural units of molten titania based slags. Hence the structure can only be clearly predicted after a theory of semiconducting properties of the slag is developed.

In another investigation of thermophysical properties of slag composed of 36-62 wt $\% \mathrm{TiO}_{2}, 0-25 \mathrm{wt} \%$ $\mathrm{Al}_{2} \mathrm{O}_{3}, 0-25 \mathrm{wt} \% \mathrm{FeO}, 19.5 \mathrm{wt} \% \mathrm{Ti}_{2} \mathrm{O}_{3}, 10 \mathrm{wt} \% \mathrm{SiO}_{2}$, $1.5 \mathrm{wt} \% \mathrm{CaO}, 1.0 \mathrm{wt} \% \mathrm{MgO}$, and $1 \mathrm{wt} \% \mathrm{MnO}$, which resulted from the smelting of titanomagnetite $/ 59 /$, it was observed that the fusibility temperature rose with an increase in $\mathrm{TiO}_{2}$ and $\mathrm{Al}_{2} \mathrm{O}_{3}$ contents and fell with an increase in $\mathrm{FeO}$ content. This conclusion was reached based on phase composition. The viscosity of this slag, over a wide range of composition, never exceeded $500 \mathrm{cps}$ at $1500^{\circ} \mathrm{C}$, rising with an increase in $\mathrm{Al}_{2} \mathrm{O}_{3}$ content above $20 \%$ and a decrease in $\mathrm{FeO}$ content.

\section{THERMOPHYSICAL PROPERTIES OF ALUMINOTHERMIC SLAGS}

Many low carbon ferroalloys such as ferrotitanium, ferrochromium, ferrovanadium, ferroniobium, ferromolybdenum, ferrozirconium, and ferrotungsten, as well as pure metals such as niobium, zirconium, molybdenum, and tungsten, are produced by metallothermic reduction, for which aluminium is usually used as the reductant (although calcium, magnesium, and zirconium have been used in some cases). Niobium production by aluminothermic reduction of niobium pentoxide has been attempted by various authors $/ 60-65 /$, as has ferroniobium production /66/. Similarly, other metals such as vanadium from vanadium pentoxide /67-70/; molybdenum from molybdenite $/ 71-73 /$, molybdenum disulphide $/ 74 /$, molybdenum trioxide $/ 75 /$, and calcium molybdate $/ 76 /$; tungsten from wolframite $/ 77 /$ and calcium tungstate $/ 78 /$; and tantalum from tantalum oxide /79-81/ have also been produced by aluminothermic reduction. Likewise, ferrotitanium is produced by aluminothermic reduction of ilmenite $/ 82-89 /$, perovskite $/ 90 /$, and also by aluminosilicothermic reduction of ilmenite /91-92/. The resultant slag in all these cases contains a high percentage of alumina $(60-70 \%)$ and unreduced oxides along with some gangue oxides. These slags have a high melting point. Therefore, a study of liquidus temperature of slags approximating aluminothermic slags, with the addition of certain basic oxides and halides, is very important because the lower the liquidus temperature, the higher the superheat available to make the slag sufficiently fluid at the working temperature.

\subsection{Liquidus Temperature of Alumina- Based Melts}

In this connection it is appropriate to quote the work of Nityanand and Fine /93/. They determined the liquidus temperature of $\mathrm{CaO}-\mathrm{Al}_{2} \mathrm{O}_{3}$ melts with 0 $10 \mathrm{wt} \% \mathrm{TiO}_{2}$. The percentage of $\mathrm{Al}_{2} \mathrm{O}_{3}$ taken in the binary mixture was $49.0-51.5 \mathrm{wt} \%$, the balance being $\mathrm{CaO}$. The liquidus lines for $\mathrm{CaO}-\mathrm{Al}_{2} \mathrm{O}_{3}-\mathrm{TiO}_{2}$ melts in air, as presented by the above authors, are reproduced in Fig. 12. It is observed that without $\mathrm{TiO}_{2}$ addition, the minimum liquidus temperature of $1647^{\circ} \mathrm{K}$ is obtained for $51 \% \mathrm{Al}_{2} \mathrm{O}_{3}$ and $49 \% \mathrm{CaO}$. The addition of $0-1 \% \mathrm{TiO}_{2}$ decreases the liquidus temperature with $\mathrm{Al}_{2} \mathrm{O}_{3} / \mathrm{CaO}$ ratio of $49 / 51$ to $51.5 / 48.5$, whereas greater $\mathrm{TiO}_{2}$ addition raises it. 


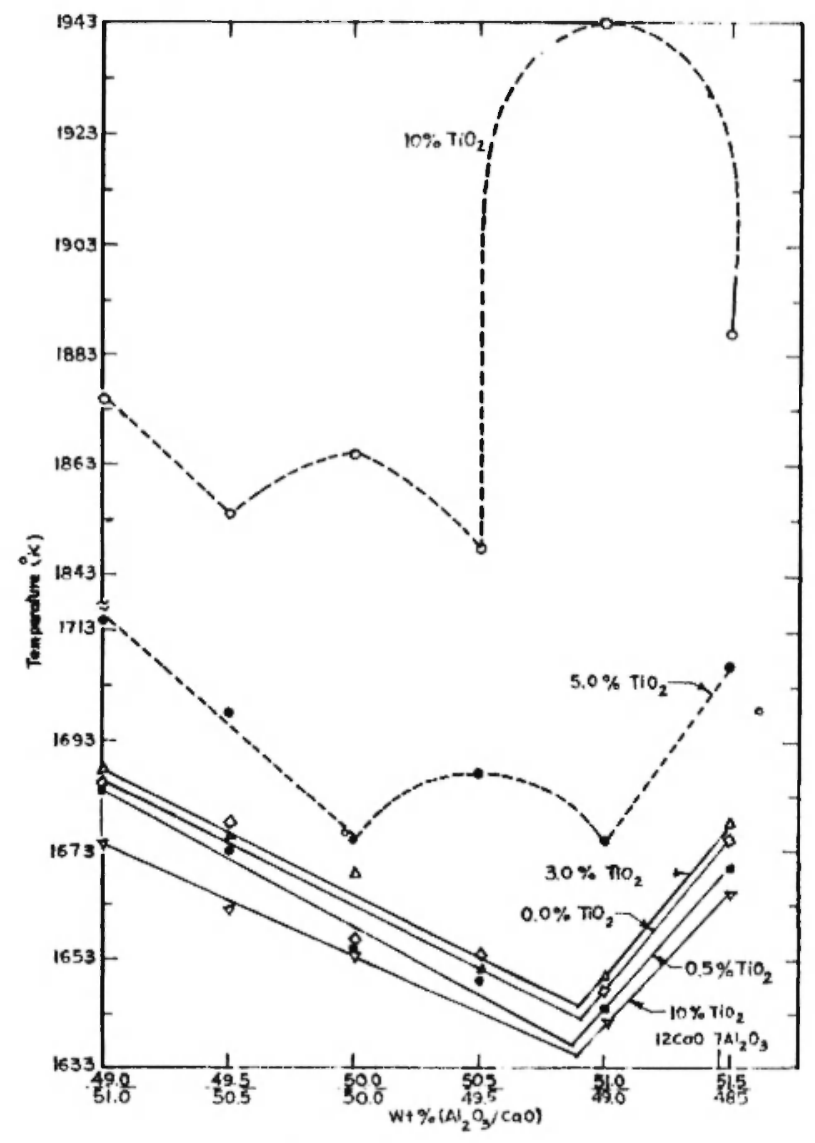

Fig. 12: The effect of additions of titanla on the liquidus line of $\mathrm{CaO}-\mathrm{Al}_{2} \mathrm{O}_{2}$ system under oxidising conditions $\left(\mathrm{PO}_{2}=0.21\right)$.

For $10 \% \mathrm{wt} \% \mathrm{TiO}_{2}$, the liquidus temperature is as high as $1943^{\circ} \mathrm{K}^{2}$ at $\mathrm{Al}_{2} \mathrm{O}_{3} / \mathrm{CaO}$ of $51 / 49$, i.e., about $300^{\circ} \mathrm{K}$ higher than that without the addition of $\mathrm{TiO}_{2}$. Measurement at low oxygen potential $\left(\mathrm{p}_{\mathrm{o} 2}=10^{-16} \mathrm{~atm}\right)$ shows that an increase in the liquidus temperature of as much as $350^{\circ} \mathrm{K}$ results due to the addition of $10 \mathrm{wt} \% \mathrm{TiO}$. Thermodynamic calculations indicate that $\mathrm{Ti}^{\mathrm{i}^{3+}}$ and $\mathrm{Ti}^{2+}$ ions may exist at low oxygen potential. Thus, to maintain electrical neutrality, some oxygen must be evolved from the melt. The aluminothermic slag for production of ferrotitanium contains $\mathrm{Al}_{2} \mathrm{O}_{3}$ and $\mathrm{TiO}_{2}$, and also $\mathrm{CaO}$ when lime is added as a flux; therefore, this knowledge of liquidus temperature will be helpful for the study of ferrotitanium slags of varying composition.

\subsection{Role of $\mathrm{CaF}_{2}$ in Aluminothermic Slags}

Calcium fluoride is said to reduce the liquidus temperature and viscosity of slags. The role of calcium fluoride in silicate slags has been discussed earlier. In the absence of $\mathrm{CaF}_{2}$, acid and high alumina slag melts exhibit high viscosity resulting from the large dimensions and low mobilities of the aggregates of complex ions such as $\mathrm{Al}_{3} \mathrm{O}_{7}^{--}, \mathrm{AlO}_{3}^{--}$, etc. in the melts. Adding fluorine ions results in the breakdown and consequent reduction in size of these complex structures, with the result that the melt exhibits high fluidity.

While carrying out a viscosity study of the slags, the container as well as conditions must be such that there will not be any reaction with the crucible or any compositional changes. In graphite crucibles $\mathrm{CaF}_{2}-\mathrm{Al}_{2} \mathrm{O}_{3}$ melts form $\mathrm{CaC}_{2}, \mathrm{Al}_{4} \mathrm{C}_{3}$, and graphite in the melt $/ 94 /$. Similarly, $\mathrm{CaF}_{2}$ will react with water and some metal oxides such as $\mathrm{SiO}_{2}, \mathrm{TiO}_{2}$, and $\mathrm{V}_{2} \mathrm{O}_{5}$ to produce $\mathrm{CaO}$ and gaseous fluorides as exemplified by the reactions:

$$
\begin{aligned}
& \mathrm{CaF}_{2}+\mathrm{H}_{2} \mathrm{O}=\mathrm{CaO}+2 \mathrm{HF}(\mathrm{g}) \\
& 3 \mathrm{CaF}_{2}+\mathrm{Al}_{2} \mathrm{O}_{3}=3 \mathrm{CaO}+2 \mathrm{AlF}_{3}(\mathrm{~g})
\end{aligned}
$$

These compositional changes can be minimized if the sample is dry and the measurement is carried out in a sealed container /95/. In practice, however, these compositional changes may not be as large as anticipated since the $\mathrm{CaO}$ formed will react to form calcium aluminates, silicates, etc., thus reducing the activities of these oxides.

It is reported that in an $\mathrm{Al}_{2} \mathrm{O}_{3}-\mathrm{CaO} \cdot \mathrm{CaF}_{2}$ ternary, Al-O complexes predominate at low $\mathrm{CaF}_{2}$ contents due to the existence of a considerable amount of covalent bonding; further, additions of $\mathrm{CaF}_{2}$ cause a gradual breakdown of the complexes $/ 95 /$.

Evseev /96/ has proposed that at low $\mathrm{CaF}_{2}$ levels the molecules of $\mathrm{Al}_{3} \mathrm{O}_{7}^{5-}$ are bound by $\mathrm{Ca}^{2+}$ ions and that any addition of fluoride ions tends to break the chains at these positions and then fill the vacant sites. Mitchell and Cameron /97/ speculated that at higher $\mathrm{CaF}_{2}$ contents networks based on $\mathrm{AlO}_{2} \mathrm{~F}_{2}^{--}$and $\mathrm{AlOF}_{2}^{-}$ are formed and that the addition of $\mathrm{CaO}$ to these melts tends to release $\mathrm{F}^{-}$ions from the networks and produce $\mathrm{AlO}_{3}^{*-}$ and $\mathrm{AlO}_{2}$ structures. Nakamura and Yanagase /98/ have suggested that $\mathrm{CaF}_{2}$ hâs little effect on the structure of aluminate anions for a $\mathrm{CaO}$ rich composition but does influence the structure of other compositions.

Viscosity determination of $\mathrm{CaO}-\mathrm{Al}_{2} \mathrm{O}_{3}-\mathrm{CaF}_{2}$ melts has been performed by several authors /99-103/. Although the reported data exhibit considerable discrepancies, they do show that viscosity is decreased by $\mathrm{CaF}_{2}$ additions and increased by $\mathrm{Al}_{2} \mathrm{O}_{3}$ additions. An increase in $\mathrm{CaO}$ content increases the viscosity slightly, as this results in slightly tighter bonding in the melt $/ 95 /$. 
In a recent investigation Yanagase et al. /104/ studied the viscosity, liquidus temperature, electrical conductivity and two-liquid regions of $\mathrm{CaO}-\mathrm{Al}_{2} \mathrm{O}_{3}$ $\mathrm{CaF}_{2}$ melts and suggested that the behaviour of $\mathrm{CaF}_{2}$ is similar to that of $\mathrm{CaO}$. The isoviscosity curves as determined are shown in Fig. 13. For the compositions where the molar ratio of $\mathrm{Al}_{2} \mathrm{O}_{3} / \mathrm{CaO}=1$, the isoviscosity and isoconductivity lines show abrupt changes, indicating that $\mathrm{Al}_{2} \mathrm{O}_{3}$ may be behaving as an amphoteric oxide as in silicate melts. In the composition range of mole $\mathrm{Al}_{2} \mathrm{O}_{3} /$ mole $\mathrm{CaO}<1$, $\mathrm{Al}_{2} \mathrm{O}_{3}$ is likely to yield complex anions such as $\mathrm{AlO}_{2}^{0-}$ and $\mathrm{AlOF}_{2}$ resulting in an increase in viscosity and a decrease in electrical conductivity with increasing alumina. In the melts where mole $\mathrm{Al}_{2} \mathrm{O}_{3} /$ mole $\mathrm{CaO}$ $>1$, behaviour of $\mathrm{Al}_{2} \mathrm{O}_{3}$ is similar to that of $\mathrm{CaO}$ in that the isoviscosity and isoconductivity lines appear to be parallel to the lines of constant $\mathrm{CaF}_{2}$.

Viscosity determinations of $\mathrm{CaF}_{2}-\mathrm{Al}_{2} \mathrm{O}_{3}-\mathrm{Nb}_{2} \mathrm{O}_{5}$ and $\mathrm{CaF}_{2}-\mathrm{Al}_{2} \mathrm{O}_{3}-\mathrm{V}_{2} \mathrm{O}_{5}$ melts show that an addition of up to $20 \% \mathrm{Nb}_{2} \mathrm{O}_{5}$ to a mixture of $70 \% \mathrm{CaF}_{2}+30 \%$ $\mathrm{Al}_{2} \mathrm{O}_{3}$ or of up to $20 \% \mathrm{~V}_{2} \mathrm{O}_{5}$ to a mixture of $70 \%$ $\mathrm{CaF}_{2}+30 \% \mathrm{Al}_{2} \mathrm{O}_{3}$ decreases the viscosity at $1600^{\circ} \mathrm{C}$ $/ 105,106 /$. However, in the case of $\mathrm{CaF}_{2}-\mathrm{Al}_{2} \mathrm{O}_{3}-\mathrm{TiO}_{2}$ melts, viscosity decreases with an additional $5 \%$ $\mathrm{TiO}_{2}$ but then increases with further addition $/ 105 /$.

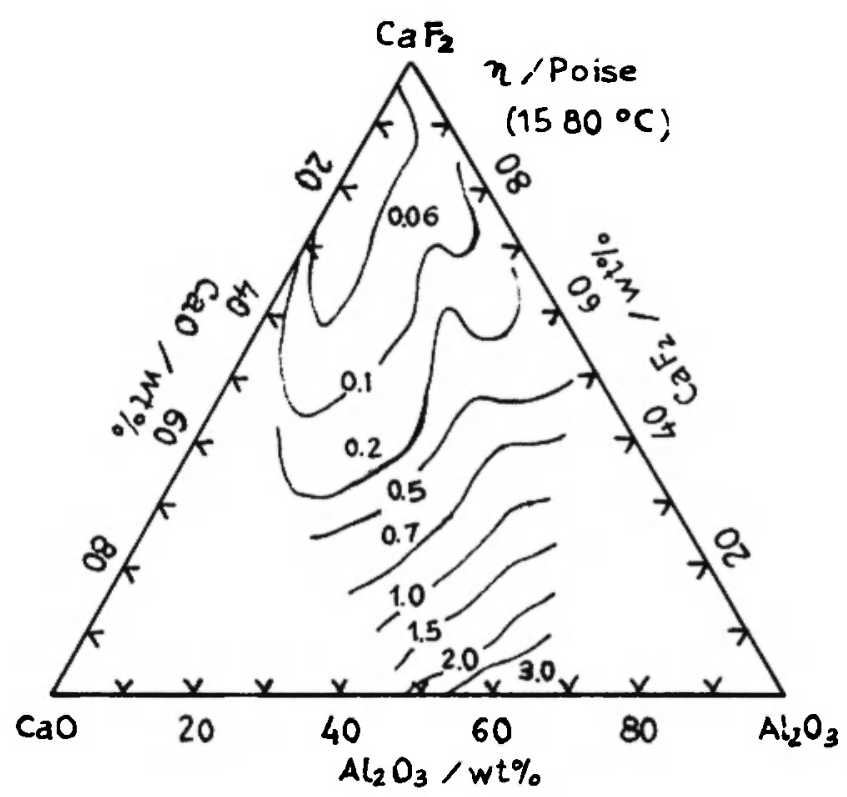

Fig. 13: $\mathrm{I}$ - Viscosity lines of $\mathrm{CaO}-\mathrm{Al}_{2} \mathrm{O}_{3}-\mathrm{CaF}_{2}$ melt at $1580^{\circ} \mathrm{C}$ under dried argon.

\subsection{Viscosity of Aluminothermic Slags}

3.3.1. Ferrotitanium slag. Suchilinkov and Pliner $/ 107 /$ studied the effect of $\mathrm{CaO}, \mathrm{BaO}$, and $\mathrm{SrO}$ on the viscosity of industrial ferrotitanium slags. The analysis of the industrial slag that they selected was $75.23 \% \mathrm{Al}_{2} \mathrm{O}_{3}, 14.25 \% \mathrm{TiO}_{2}, 5.31 \% \mathrm{CaO}, 3.29 \% \mathrm{FeO}$, $0.75 \% \mathrm{SiO}_{2}$, and $1.16 \% \mathrm{MgO}$. To two slag samples they added $\mathrm{CaO}$ in order to form a slag of $9.0 \%$ and $14 \% \mathrm{CaO}$. To the other two slag samples, $4.0 \%$ and $9.0 \% \mathrm{BaO}$ and to a fifth slag sample, $5 \% \mathrm{SrO}$ were added. The effects of these additions on viscosity at various temperatures are shown in Fig. 14. As seen in the figure, $\mathrm{CaO}$ exerts a greater effect than $\mathrm{SrO}$ and $\mathrm{BaO}$ in reducing the viscosity. The nature of viscosity and temperature relationship shows that the temperature has little effect on viscosity when the slags are overheated well above the liquidus (1550$1650^{\circ} \mathrm{C}$ ). The viscosity value of the slag with $14 \%$ $\mathrm{CaO}$ was about $130 \mathrm{cps}$ at a temperature above $1550^{\circ} \mathrm{C}$.

In another investigation Pliner et al. /108/ measured viscosity in the slags obtained during industrial production of ferrotitanium (A), special purpose lowcarbon ferrochrome (B), ferrosilicozirconium (C), and ferroniobium $\left(D_{1}\right.$ and $\left.D_{2}\right)$. The chemical analyses of these slags are contained in Table 3. Because a certain amount of metal remains in industrial slags in the form of beads and very small metallic inclusions arising as a result of decomposition of lower

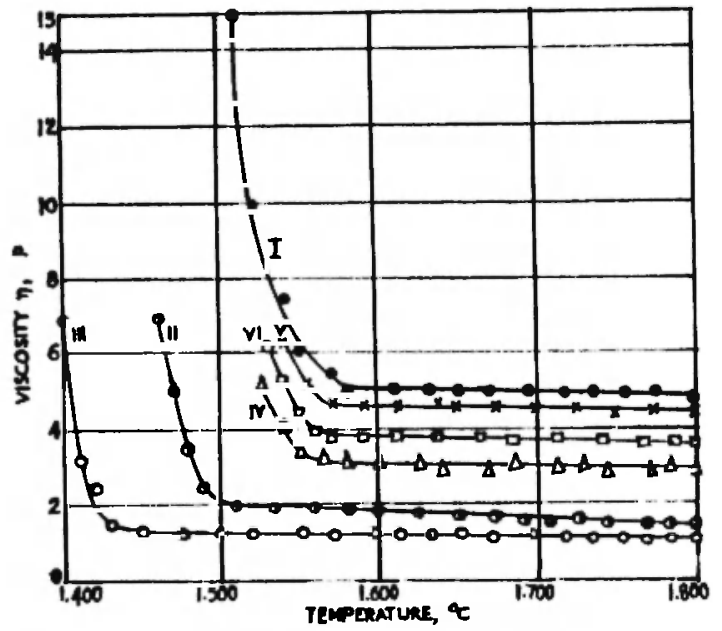

Fig. 14: Effect of $\mathrm{CaO}, \mathrm{SrO}$ and $\mathrm{BaO}$ additions on viscosity of industrial ferrotitanium slags. I- No addition, II \& III - CaO addition (9 and $14 \mathrm{wt} \%$ ), IV SrO addition $5 \mathrm{wt} \%, \mathrm{~V} \& \mathrm{VI}-\mathrm{BaO}$ addition (4 and 9 $w t \%)$. 
TABLE 3

CHEMICAL COMPOSITION OF INVESTIGATED SLAGS

\begin{tabular}{lrrrrrrrl}
\hline Alloy & $\mathrm{Al}_{2} \mathrm{O}_{3}$ & $\mathrm{CaO}$ & $\mathrm{MgO}$ & $\mathrm{FeO}$ & $\mathrm{SiO}_{2}$ & $\mathrm{TiO}_{2}$ & $\mathrm{ZrO}_{2}$ & $\Sigma \mathrm{Me}$ \\
\hline Ferrotitanium (A) & 60.6 & 12.8 & 4.74 & 1.67 & 2.96 & 10.11 & - & 6.70 \\
Low-carbon ferrochrome (B) & 54.0 & 22.2 & 12.20 & 1.38 & 0.97 & - & - & $0.93\left(\mathrm{C}_{\mathrm{r}}\right)$ \\
Ferrosilicozinconium $\left(\mathrm{C}_{1}\right)$ & 54.6 & 30.8 & 5.12 & 0.91 & 2.66 & - & 5.57 & - \\
Ferrosilicozirconium $\left(\mathrm{C}_{2}\right)$ & 19.9 & 32.5 & 6.21 & 0.35 & 25.84 & - & 15.20 & - \\
Ferroniobium $\left(\mathrm{D}_{1}\right)$ & 55.0 & 20.2 & 2.07 & 1.30 & 5.78 & 7.78 & 2.92 & $4.21(\mathrm{Nb})$ \\
Ferroniobium $\left(\mathrm{D}_{2}\right)$ & 73.5 & 16.0 & 7.30 & 1.75 & 0.44 & 0.29 & 0.43 & $0.01(\mathrm{Nb})$ \\
\hline
\end{tabular}

oxides may also be found, the composition of metallic content was also determined in each slag.

As shown in Fig. 15A, the ferrotitanium slag is a short slag for which viscosity drops steeply within a range of only $50^{\circ} \mathrm{C}$. This slag, however, has very low viscosity values, ranging from $150 \mathrm{cps}$ at $1830^{\circ} \mathrm{C}$ to $180 \mathrm{cps}$ at $1760^{\circ} \mathrm{C}$. The curve illustrated in Fig. $15 \mathrm{~A}$ can be used as a basis for selecting the temperature for industrial production of ferrotitanium. According to the published data $/ 109 /$, the temperature of the melt at the moment when the reducing reactions finish should exceed by $250^{\circ} \mathrm{C}$ the minimum temperature at which deposition of the metal droplets through the molten slag is possible. This minimum temperature from the figure can be taken as $1750^{\circ} \mathrm{C}$, i.e., the temperature at which there is a steep viscosity rise.

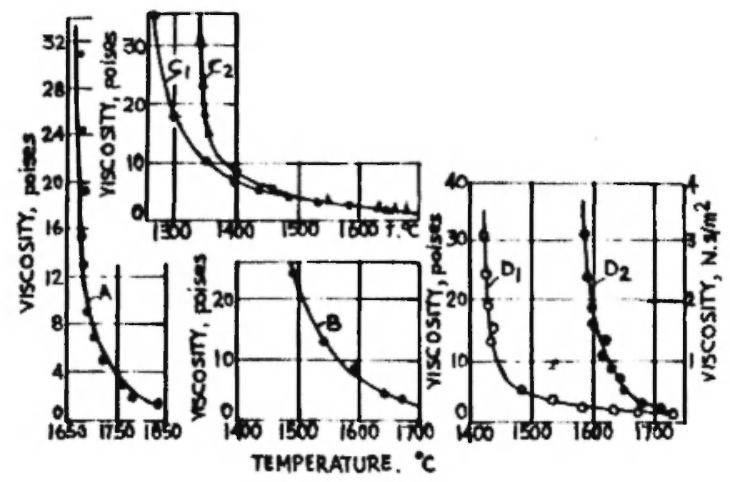

Fig. 15: Viscosity of slags investigated in the production of ferroalloys as a function of temperature (nomenclature as in Table III).
3.3.2. Low carbon ferrochrome slag. In the case of this slag $/ 108 /$, it can be seen from Fig. 15B that viscosity variation with respect to temperature is gradual. The uniform increase in viscosity of the slag as it cools down over a wide temperature range helps in a complete separation of slag from metal, allowing the alloy to be obtained without much metal loss in the form of beads in the slag.

3.3.3. Ferrosilicozirconium slag. The viscosity of this slag obtained $/ 108 /$ by two different methods is shown in Fig. 15C. Here also there is a gradual change of viscosity with temperature, as with ferrochrome slag. The presence of a high quantity of zirconium dioxide in the slag, however, does not bring about any essential change in the viscosity in comparison to that of lime-alumina slag with a $\mathrm{Al}_{2} \mathrm{O}_{3} / \mathrm{CaO}$ ratio of $60: 40$, as reported by Kozakevitch $/ 110 /$.

3.3.4. Ferroniobium slag. Viscosity of ferroniobium slag produced from pyrochlore concentrate $\left(D_{1}\right)$ and niobium pentoxide $\left(D_{3}\right) / 108$ / in the high temperature region (around $1700^{\circ} \mathrm{C}$ ) is almost the same, as shown Fig. $15 \mathrm{D}$, but in the former, a sudden change of viscosity takes place at lower temperatures $\left(1420-1540^{\circ} \mathrm{C}\right)$. Accordingly, producing ferroniobium from pyrochlore concentrate $\left(\mathrm{D}_{1}\right)$ under industrial temperature conditions should enable better separation of slag from metal and hence less metallic beads should appear in the slag. However, as is apparent from considering Table 3 , slag $\mathrm{D}_{2}$ has better separation than slag $D_{1}$. It has been pointed out $/ 108 /$ that this may be due to a decrease in interphase tension between the slag and the metal in the case of slag $\mathrm{D}_{1}$. 


\section{CONCLUSIONS}

The review of literature shows that there is a wide scope for a thorough and systematic investigation of the liquidus temperature, conductance, and viscosity of slag-melts resulting from metallothermic production of various less common metals and their ferroalloys such as $\mathrm{Fe}-\mathrm{Ti}, \mathrm{Fe}-\mathrm{V}, \mathrm{Fe}-\mathrm{Mo}, \mathrm{Fe}-\mathrm{W}, \mathrm{Fe}-\mathrm{Nb}$, etc. A detailed study with additions of various fluxing constituents such as $\mathrm{CaO}, \mathrm{MgO}$, and $\mathrm{CaF}_{2}$, would throw some light on the structural aspects of aluminothermic slags. Such an investigation would also help in selecting an appropriate slag composition for better slag-metal separation. Determination of the relationship between viscosity and temperature would help in selecting the optimum temperature conditions for a heat, ensuring the most effective separation of the metal from the slag and thus increasing the recovery of the important metal and the yield of the ferroalloy.

\section{REFERENCES}

1. Bockris, J.O'M., Kitchener, J.A., Ignatowiez, S., and Tomlinson, J.W. Trans. Faraday Soc., 48, 75-91 (1952).

2. Bockris, J.O'M., Kitchener, J.A. and Davies, A.E., Chem. Physics, 19, 255-260, (1950).

3. Bockris, J.O'M., Mackenzie, J.D. and Kitchener, J.A. Trans. Faraday Soc, , 51, 1734-1748 (1955).

4. Bockris, J.O'M., Tomlinson, J.W. and White, J.L., Trans. Faraday Soc, 52, 299-310 (1956).

5. Richardson, F.D., Physical Chemistry of Melts in Metallurgy, Vol. I, Academic Press, London (1974).

6. Bockris, J.O'M. and Lowe, D.C., Royal Soc., 226, 423435 (1954)

7. Mackenzie, J.D., Chem. Rev., 56, 455-470 (1956).

8. Callow, R., J. Soc. Glass Tech., 36, 137 (1952).

9. Toop, G.W. and Samis, C.S., Trans. of the Met. Soc. of AlME, 224, 878-887 (1962).

10. Toop, G.W. and Samis, C.S., Can. Met. Quarterly, 1, 129-151 (1962).

11. Mackenzie, J.D., Trans. Faraday Soc, 53, 1488-1493 (1957).

12. Gupta, V.K. and Seshadri, V., Silver Jubilee Symposium, Processs Metallurgy, Ind. Inst. Met., 203-218 (1972).

13. Kozakevitch, P., International Symp. on Physical Chemistry of Process Metallurgy, AlME, 7, 97-116 (1959).

14. Machin, J.S., and Hanna, D.L. J. Am. Ceram. Soc., 28 , 310-316 (1945).

15. Moore, H. and McMillan, P.W., J. Soc. Glass Tech., 40 193 (1956).

16. Seshadri, V. and Gupta, V.K., Arch. Eisenüttenwes, 45, 337-338 (1974).
17. Dutz, H. and Schulz, G.W., Glass Tech. Ber., 42, 89 (1969).

18. Turkdogan, E.T. and Bills, P.M., Am. Ceram. Bull, 39, 682-687 (1960).

19. Machin, J.S. and Yee, T.B., J. Am. Ceram. Soc., 31, 200-204 (1948).

20. Machin, J.S., Yee, T.B., Hanna, D.L., J. Am. Ceram. Soc., 35, 322-325 (1952).

21. Machin, J.S. and Yee, T.B., J. Am. Ceram. Soc., 37, 177-186 (1954).

22. Yakushev, Romashin, V.M. and Amfiteatrov, V.A., Steel in USSR, 7, 617-618 (1977).

23. Kawahara, M., Morinaga, K.J. and Yanagase, T., Can. Metal. Quarterly, 22, 143-147 (1983).

24. Hill, O. and Audreith, L., J. Phys. Coll. Chem., 54, 690 (1950).

25. Kozakevitch, R., Rev. Met, 51, 569-587 (1954).

26. Bills, P.M., JISI, 20, 133-140 (1963).

27. Baak, T., Proc. Conf. Phy. Chem. Iron and Steel Making, Dedham, Mass., 1956. Wiley \& Sons, New York (1958).

28. Baak, T. and Olander, A., Acta. Chem. Scand., 9, 1950 (1955).

29. Kalim, A., B. Tech. Project Report, IIT Kanpur (1970).

30. Gupta, V.K. and Seshadri, V., Trans. Ind. Inst. Met., 29, 103-106 (1976).

31. Kato, M. and Minowa, C., Trans. ISIJ, 9, 31-38 (1969).

32. Kozakevitch, P., Rev. Met., 46, 572 (1949).

33. Kozakevitch, P., Rev. Met., 52, 161-172 (1955).

34. Seki, K. and Oeters, F., Trans. ISIJ, 24, 445-454 (1984).

35. Nesterenko S.V. and Khomenko, V.M., Russian Met., 5, 35-39 (1982).

36. Galatonov, A.L., Stal in English, 6, 425-429 (1964).

37. Sokolov, G.A. and Gul'tyai, I.I., Stal in English, 12, 951-955 (1965).

38. Yakubtsiner, N.M., Manchinskii, V.G. and Panyshin, L.A., Stal in English, 3, 184-190 (1968).

39. Singh, N., Mulhukrishnan, V. and Ragozinski, T., MML Technical Joumal, 12, 12-21 (1970).

40. Gupta, V.K. and Seshadri, V., Trans. Ind. Inst. Met., 26, 55-64 (1973).

41. Singh, R.N., Steel India, 7, 73-83 (1984).

42. Fine, H.A. and Arac, S., Ironmaking and Steelmaking, 7, 160-166 (1980).

43. Singh, B.N., Singh, D.P. and Chatterjee, L.M., TISCO Tech. Jl., January, 10-17 (1973).

44. Athappan, R. and Nikulin, Y.F., Steel India, 7, 75-85 (1986).

45. Ross, H.V., J. of Metals, 407-411 (1958).

46. Mikhailov and Belyakova, Ural Met., 6, 7-9 (1939).

47. Semik, I.P., Bull Acad. Sci. USSR, 4, 55-66 (1941).

48. Ohno, A. and Ross, H.U., Can. Met. Quarterly, 2, 243258 (1963).

49. Ohno, A. and Ross, H.U., Can. Met. Quarterly, 2, 259 279 (1963). 
50. Zhilo, N.L., et al. Izv. Akad. Nauk. SSSR Metally., 6, 3-8 (1969).

51. Zhilo, N.L., et al., Izv. Akad. Nauk. SSSR Metally, 1, 65-69 (1970).

52. Handfield, G., Charette, G.G. and Lee, H.Y., Light Metals, AIME, New York (1971).

53. Handfield, G., Charette, G.G. and Lee, H.Y,J. Metals, 1-4 (1972).

54. Miller, V.Ya. and Babushkin, N.M., Stal in English, 5, 314-318 (1961).

55. Handfield, G. and Charette, G.G., Can. Met. Quarterly, 10, 235-243 (1971).

56. Wyatt, J.L., Trans. AMIE, 188, J. Metals, 989-994 (1950).

57. Reznichenko, V.A., Izv. Akad. Nauk. SSSR Metally., 5, 43 (1967).

58. Denisov, S.I. and Degtyarecev, V.A., Izv. Akad. Nauk. SSSR Metally, 1, 80 (1970).

59. Morozov, A.A., Karyazin, I.A., Reznichenko, V.A. and Olyunina, T.V., Russian Met., 5, 30-34 (1982).

60. Von Bolten, W.Z., Electrochem., 13, 145-149 (1907).

61. Mondolfo, L.F., U.S. Patent No. 2803536 (1957).

62. Wilhelm, H.A., Schmidt, F.A. and Ellias, T.G., J. Metals, 18, 1303-1308 (1966).

63. Gupta, C.K. and Jena, P.K., Trans. Ind. Inst. Metals, 22, 51-52 (1969).

64. Kamat, G.R. and Gupta, C.K., Met. Trans., 2, 2817 2823 (1971).

65. Narayana, C., Mukherjee, T.K., Bose, D.K. and Gupta, C.K., Trans. Ind. Inst. Met., 30, 387-394 (1977).

66. Mehra, O.K., Taneja, A.K., Gupta, C.K. and Jena, P.K., Trans. Ind. Inst. Met., 24, 66-70 (1977).

67. Carlson, O.N., Schmidt, F.A. and Krupp, W.E., J. Metals, 18, 320-323 (1966).

68. Bose, D.K. and Jena, P.K., Trans. Ind. Inst. Met., 23, 56-59 (1970).

69. Pillai, P.V.S., Nayar, K.U., Mukherjee, T.K. and Gupta, C.K., Trans. Ind. Inst. Met., 26, 24-30 (1973).

70. Mehra, O.K. and Gupta, C.K., Met. Trans. (B), 8, 683685 (1977).

71. Gupta, C.K. and Jena, P.K., J. Less Common Met., 14, 148-152 (1968).

72. Venkataramani, R., Bose, D.K. and Jena, P.K., Trans. Ind. Inst. Met., 23, 13-19 (1970).

73. Mehra, O.K., Bose, D.K. and Gupta, C.K., Trans. Ind. Inst. Met., 26, 1-7 (1973).

74. Mehra, O.K., Gupta, C.K. and Jena, P.K., Trans. Ind. Inst. Met., 21, 45-48 (1968).

75. Schmidt, F.A., Bergman, R.M., Carlson, O.N. and Wilhelm, H.A., J. of Metals, 23, 38-44 (1971).

76. Mehra, O.K., Bose, D.K. and Gupta, C.K., Met. Trans., 4, 691-694 (1973).

77. Gupta, C.K. and Jena, P.K., J. Less Common Met., 13, 269-273 (1967).

78. Belitskus, D., J. Metals, 25, $39-44$ (1973).

79. Gupta, C.K. and Jena, P.K., J. Metals, 20, 25-28 (1968).
80. Wilhelm, H.A., Bergmann, R.M. and Schmidt, R.A., J. Metals, 22, 45-49 (1970).

81. Nayar, K.U., Mukherjee, T.K. and Gupta, C.K., J. Less Common Met, 21, 87-91 (1975).

82. Gissen, K. and Dautzenberg, W., Stahl und Eisen, 159-162 (1948).

83. Bhatnagar, P.P. and Nijhawan, B.R., Proc. Symp. Ferroalloy Indust. in India, NML, Jamshedpur, 8388 (1962).

84. Nijhawan, B.R., ibid., 42-51.

85. Zanos, S., Dezso, H., Istuana, H., Zanos, B. and Geja, V. Hungany Teljes, 7, 1513 (1971).

86. Behera, R.C., Mohanty, A.K. and Misra, S., Trans. Ind. Inst. Met, 31, 201-204 (1973).

87. Behera, R.C. and Mohanty, A.K., Proc. Symp. 'All India Seminar Recent Trends in Ferroalloys Techy', Nagpur, 119-124 (1977).

88. Behera, R.C., Mohanty, A.K. and Misra, S., Trans. Ind. Inst. Met., 34, 421-426 (1981).

89. Povlov, V.A. and Suchilinkov, S.I., Metalloterm, Protsossy, khim. Met. Mater. Knof, 218-227 (1971).

90. Kumysh, I.S., Stal in English, 3, 185-188 (1960).

91. Hussain, M.K., Khalil, S.E. and Belal, A.M., Egypt.J. Chem., 15, 145-156 (1972).

92. Behera, R.C. and Mohanty, A.K., Trans. Ind. Inst. Met., 37, 2 15-219 (1984).

93. Nityanandaa, N. and Fine, H.A., Met. Trans. B, 14, 685-692 (1983).

94. Yakovlev, N.F., Nikitin, B.M., Voronov, V.A., Rajchenko, T.F. and Prokhorov, A.N., Izv. Akad. Nauk. Met., 2,8 (1977).

95. Mills, K.C. and Kenne, B.J., Intemat. Met. Rev., 1, 21 69 (1981).

96. Evseev, P.P., Autom. Weld (USSR), 20, 42 (1967).

97. Mitchell, A. and Cameron, J., Met. Trans., 2, 3361 (1971).

98. Nakamura, T. and Yanagase, T., J. Japan Inst. Met., 41, 165 (1977).

99. Povolotskii, D.Ya., Voronov, V.A. and Nikitin, B.M., Steel. USSR, 1, 952 (1971).

100. Stepanaov, V.V. and Lopaev, B.E., Autom. Weld (USSR), 20, 46 (1967).

101. Davies, M.W. and Wright, F.A., Chent. Ind, 359 (1970).

102. Zhmoidin, G.I. and Moldavskiy, O.D., Russ. Met., 1, 42 (1970).

103. Murataov, A.M., Russ. Met., 3, 51 (1972).

104. Yanagase, T., Morinaga, K., Ohta, Y. and Ajura, T., 'Intern. Symp. Metallurgical Slags and Fluxes, TMSAIME, Warrandale, Pa.', 995-1004 (1984).

105. Isotomin, S.A., Lepinskikh, B.M., Manakov, A.I. and Krasikov, S.V., 'Viscosity of fluoride-oxide melts containing variable valence oxides'. Report No. 220275, VINITI (1975).

106. Isotomin, S.A., Lepinskish, B.M., Manakov, A.I. and Pokrovskii, V.A., 'Surface tension of fluoride oxide 
melts containing variable valence oxides,' Report $\uparrow$ Jo. 2205-75, VINITI (1975).

107. Suchilinkov, S.I. and Pliner, Y.L., Stal in English, 11, 822-824 (1961).

108. Pliner, Y.L., Shtengelmeier, S.V., Mikhaililinkov,
S.V., Ignatenko, F.G. and Rubinshtein, E.A., Stal in English, 4, 284-286 (1966).

109. Pliner, Y.L. and Suchilinkov, S.I., Izvest. VUZ, Chernaya Met., 7 (1961).

110. Kozakevitch, P., Rev. Met., 57, 149-160 (1960). 
